DIW BERLIN

Discussion

Papers

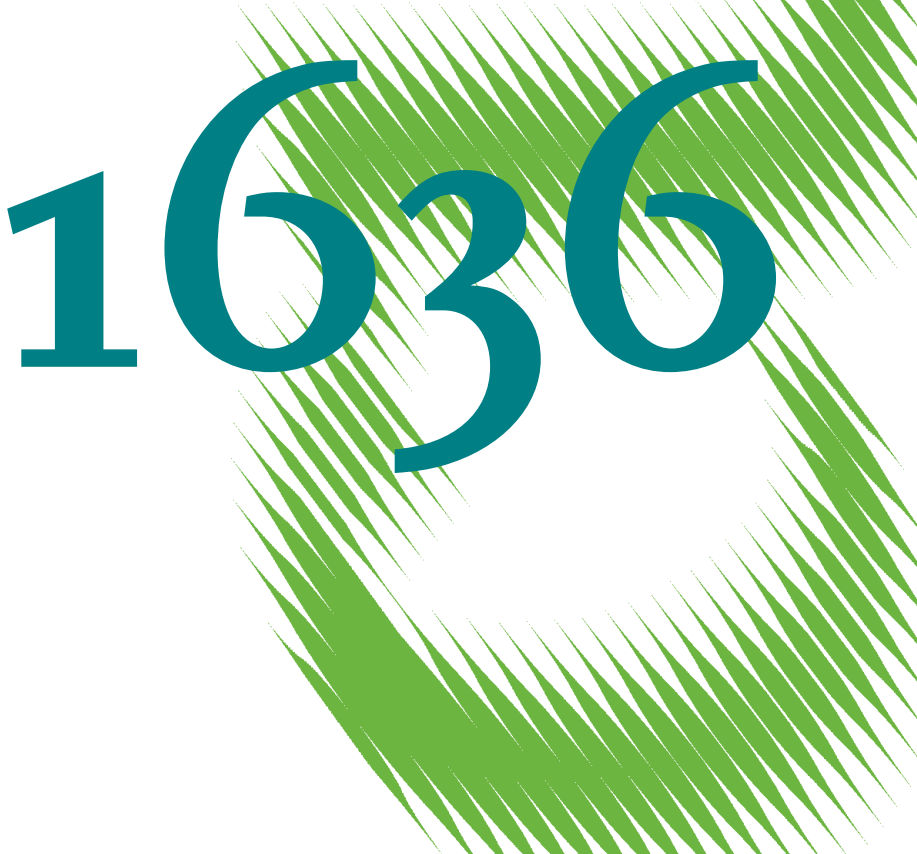

Bank-Specific Shocks and House Price Growth in the U.S. 
Opinions expressed in this paper are those of the author(s) and do not necessarily reflect views of the institute.

IMPRESSUM

(C) DIW Berlin, 2017

DIW Berlin

German Institute for Economic Research

Mohrenstr. 58

10117 Berlin

Tel. +49 (30) $89789-0$

Fax +49 (30) $89789-200$

http://www.diw.de

ISSN electronic edition 1619-4535

Papers can be downloaded free of charge from the DIW Berlin website:

http://www.diw.de/discussionpapers

Discussion Papers of DIW Berlin are indexed in RePEc and SSRN:

http://ideas.repec.org/s/diw/diwwpp.html

http://www.ssrn.com/link/DIW-Berlin-German-Inst-Econ-Res.html 


\title{
Bank-Specific Shocks and House Price Growth in the U.S.
}

\author{
Franziska Bremus* Thomas Krause ${ }^{\dagger} \quad$ Felix Noth ${ }^{\ddagger}$
}

January 2017

\begin{abstract}
This paper investigates the link between mortgage supply shocks at the banklevel and regional house price growth in the U.S. using micro-level data on mortgage markets from the Home Mortgage Disclosure Act for the 1990-2014 period. Our results suggest that bank-specific mortgage supply shocks indeed affect house price growth at the regional level. The larger the idiosyncratic shocks to newly issued mortgages, the stronger is house price growth. We show that the positive link between idiosyncratic mortgage shocks and regional house price growth is very robust and economically meaningful, however not very persistent since it fades out after two years.
\end{abstract}

JEL-Classifications: E44, G21, R20

Keywords: House Prices, Idiosyncratic Shocks, Granularity, Credit Supply.

\footnotetext{
${ }^{*}$ German Institute for Economic Research (DIW Berlin), fbremus@diw.de

${ }^{\dagger}$ Halle Institute for Economic Research (IWH), Thomas.Krause@iwh-halle.de

${ }^{\ddagger}$ Halle Institute for Economic Research (IWH) and Otto-von-Guericke University Magdeburg (OVGU), Felix.Noth@iwh-halle.de

Financial support from the German National Science Foundation (DFG) in the context of the Priority Programme SPP 1578 "Financial Market Imperfections and Macroeconomic Performance" is gratefully acknowledged. Thomas Krause thanks the International Association for Applied Econometrics (IAAE) for providing a travel grant. We thank Claudia Buch, Manuel Buchholz, Rainer Haselmann, Mathias Klein, Michael Koetter, Lena Tonzer, and participants of workshops and conferences at the 2016 SPP 1578 meeting, the 2016 IAAE meeting, the 2016 SYME meeting, the Halle Institute for Economic Research (IWH), and the Goethe University Frankfurt for helpful comments. Hanna Schwank provided excellent research assistance. The data used in this paper are publicly available. All remaining errors and inconsistencies are our own.
} 


\section{Motivation}

Building on the concept of granularity (Gabaix, 2011), this paper investigates the role of micro-level mortgage supply shocks for aggregate house price growth across U.S. regions. The idea is that bank-specific shocks to mortgage origination can impact macroeconomic variables if concentration in the mortgage market is very high. If a few large mortgage lenders dominate the market, diversification effects are dampened, such that idiosyncratic lending shocks can lead to movements in aggregate mortgage supply and house prices.

Indeed, mortgage market concentration has increased substantially since the 1990s. While the top $1 \%$ of U.S. banks supplied $50 \%$ of mortgages in 1991, they accounted for almost $80 \%$ of total mortgages in 2007 . In addition, Figure 1 illustrates that mortgage lending accounts for an increasing fraction of the overall credit business: while mortgages made up for less than one quarter of total loans in the U.S. at the beginning of the 1990s, the ratio of mortgages to total loans has significantly increased during the run-up to the financial crisis. In 2010, it stood at roughly $45 \%$. Regarding the macroeconomic consequences of these developments, the literature shows that mortgage lending is an important driver of macroeconomic vulnerabilities (Jorda et al., 2016).

While several previous studies focus on the role of aggregate credit for house prices and macroeconomic performance, our analysis extends the literature by shifting the focus toward bank-specific, granular effects. Given that risk at the level of individual financial institutions can harm aggregate economic stability, this paper asks whether idiosyncratic changes in the mortgage supply of large banks impact house price growth and, hence, macroeconomic performance. It thus aims at shedding light on how sensitive the U.S. housing market reacts to idiosyncratic credit supply shocks.

We analyze the nexus of bank-specific mortgage supply shocks and house price dynamics 
in U.S. regions in two steps. First, we examine if the degree of concentration in the market for newly issued mortgages is high enough for granular effects on regional house prices. Second, we investigate whether and how bank-specific mortgage supply shocks drive house price movements at the regional level.

At first glance, idiosyncratic shocks should not matter for aggregate outcomes. Bankspecific events, including financial innovations, fine payments, computer glitches, and unexpected managerial decisions, should not have any far-reaching power beyond the microlevel in an economy with a large number of firms and banks, like the United States. If firm sizes were normally distributed, the law of large numbers would smooth out the impact of idiosyncratic shocks, ultimately showing negligible effects on aggregate variables. However, if markets are highly concentrated, as they are in manufacturing (Di Giovanni et al., 2011) and especially in banking (Bremus et al., 2013), such diversification effects are dampened. Gabaix (2011) demonstrates, both theoretically and empirically, that a fat-tailed power law distribution of firm sizes implies a significant role of idiosyncratic, firm-level shocks for aggregate volatility. Intuitively, idiosyncratic fluctuations of the sales of Nokia cannot be easily counteracted by other firms, exposing Finland's economic activity to the fates of one big market player. Gabaix (2011) labels this phenomenon as "Granularity" and presents evidence that firm-specific shocks hitting the largest manufacturing firms in the U.S. explain one-third of aggregate output fluctuations.

We apply the the concept of granularity to the U.S. financial market. Our analysis of granular mortgage market effects yields four important findings. First, we provide evidence that the mortgage market is highly concentrated at the level of U.S. Metropolitan Statistical Areas (MSAs). Estimations of the power law coefficient of the regional distributions of new mortgages show that mortgage size follows a power-law with a fat right tail in all MSAs. Thereby, we can show that the necessary condition for granular effects to emerge from the 
mortgage market is fulfilled at our level of analysis, the MSA-level.

Second, our estimation results reveal a positive and statistically significant link between idiosyncratic shocks to newly issued mortgages and regional house price growth. This result is in line with previous findings from the granularity-literature and confirms that credit shocks at the micro-level can translate into aggregate movements. The larger that the shocks to mortgage lending at the bank-level are, the greater is house price growth. Hence, the presence of large mortgage lenders amplifies the effects of idiosyncratic mortgage supply shocks compared to less concentrated markets. Our findings are not only robust to alternative model specifications, but also to an instrumental variable (IV) approach where our measure of mortgage supply shocks is instrumented by a branching deregulation event in the U.S. banking market

Third, the effect of bank-specific shocks to mortgage origination on house prices depends on the elasticity of housing supply. The more inelastic housing supply is, the more do micro-level mortgage supply shocks drive house prices. Intuitively, in regions where the extension of housing supply is limited, e.g., for geographical reasons, a positive housing demand shock triggered by easier mortgage supply drives up house prices more than in regions where housing supply can be extended more easily.

And fourth, based on a conservative IV-setting, we find that the positive effects of idiosyncratic mortgage shocks on house price growth fade out after two years. In light of the literature showing that common shocks affect house prices over a period of five years (Favara and Imbs, 2015), these shorter-lived effects of idiosyncratic shocks in mortgage origination seem reasonable.

Our identification strategy rests on three features. First, micro-level data from the Home Mortgage Disclosure Act (HMDA) on mortgage applications enable us to employ information on newly issued mortgages, whereas the bank balance sheet data used in 
several previous studies just provide outstanding stocks of loans, from which newly issued loans can only be proxied. Second, the HMDA data allow for assigning mortgages to the region they are supplied to, such that bank-specific shocks can be precisely linked to the region they affect. We aggregate each bank's mortgage supply at the level of MSAs. Since the banks in our sample lend to multiple regions, we can follow the identification strategy by Khwaja and Mian (2008) to reduce concerns that our shock measure is plagued by regional demand factors. Third, to reduce any remaining concerns on reverse causality or omitted variable bias, we instrument our micro-level shock measure by a variable indicating U.S. branching deregulation. Thus, we can significantly increase the internal validity of the estimation of granular effects from the banking sector.

To put the contribution of our results into perspective, note that standard asset pricing literature suggests that house prices should equal the sum of expected income payoffs from renting a house (Allen and Gale, 2007). Hence, the price of housing assets should depend only on their expected return, regardless of how the asset purchase is financed. ${ }^{1}$ Yet, the literature underlines that cheaper credit is one of the main factors driving house price increases: In a theoretical paper, Justiniano et al. (2015) show that empirical features of the housing boom can be best explained by looser lending constraints in the mortgage market, not by borrowing constraints. Empirical evidence by Adelino et al. (2012) reveals that easier credit supply positively affects house prices. Mian and Sufi (2009) show that securitization led to an extension in subprime mortgages and, finally, to increased house price growth over the 2002-2005 period. In a similar vein, Di Maggio and Kermani (2016) find that U.S. counties with greater mortgage origination have seen higher house price increases in booms, and steeper house price reductions during busts. Based on U.S. branching deregulation as an instrument for credit growth, empirical findings by Favara and Imbs (2015) support that

\footnotetext{
${ }^{1}$ Kindleberger (1978) was the first to challenge that view and argue that the ability to borrow money impacts asset prices.
} 
access to credit is an important driver of house prices - both in statistical and economical senses.

- Insert Figure 1 here -

Regarding the macroeconomic consequences of movements in mortgage supply and house prices, based on historical credit data, Jorda et al. (2016) highlight that the importance of mortgage credit in financial sector activity has significantly increased over time, so that banks and households have levered up substantially. They identify mortgage booms as one important reason for financial as well as real fluctuations. Loutskina and Strahan (2015) show that financial integration within the U.S. has led to a closer link between house price developments and the real economy. The amplified effect of collateral shocks on the real economy has increased macroeconomic volatility. According to the household balance sheet view of Mian and Sufi (2014), macroeconomic performance in the U.S. crucially depends on household debt dynamics. The evolution of household debt, in turn, is linked to house prices: the larger the growth in house prices, and hence in home equity, the more that leverage builds up in the household sector, such that default risk rises. In case of a sudden drop in house prices, households have to deleverage, which depresses private consumption and, hence, aggregate demand. Thus, linkages between the credit market and house prices appear to be a crucial determinant of macroeconomic performance. Consequently, our question of whether idiosyncratic mortgage supply shocks matter for house price developments in concentrated mortgage markets is important for the regulatory debate over micro- and macroprudential policies.

Our study is most closely related to the literature on granular origins of aggregate fluctuations in the banking sector. Blank et al. (2009) were the first to measure granular effects from banking to investigate how bank concentration affects the stability of the Ger- 
man banking system. Using a panel of Eastern European countries, Buch and Neugebauer (2011) find significant effects of idiosyncratic shocks to large banks on the real economy. Using a linked bank-firm level data set, Amiti and Weinstein (2016) demonstrate that idiosyncratic credit supply shocks explain about $40 \%$ of aggregate loan and investment fluctuations in Japan. Bremus et al. (2013) provide a general equilibrium model of granular effects from the credit market and find empirical support that bank-specific credit shocks affect the macroeconomy in a large set of countries.

For the large and well diversified U.S. economy, the evidence on granular effects from the banking sector is so far very limited. One exception is the study by Landier et al. (2016), who demonstrate that - due to high concentration and hence granular effects - financial integration is an important driver of the increased synchronization of house prices across U.S. states. We add to this literature by studying how market structure in the U.S. mortgage market affects economic performance in terms of regional house price developments.

The following section presents the data and our empirical methodology. Section 3 discusses the estimation results, while Section 4 concludes.

\section{Data and Methodology}

In order to test whether bank-specific mortgage supply shocks affect house price movements at the regional level, we proceed in three steps. First, we calculate idiosyncratic shocks to mortgage supply. Second, a measure of granular effects from the regional mortgage market is constructed using banks' regional mortgage market shares. We then regress regional house price growth on this measure of granular effects from the mortgage market. 


\subsection{Granular Effects from the Mortgage Market}

Intuitively, the idea behind granular effects from the mortgage market is that idiosyncratic shocks matter for aggregate house prices if concentration is high enough. If the market shares of the players in the credit market are relatively equal, then idiosyncratic shocks cancel out across a large number of banks. Yet, when concentration is high, such that the largest players dominate the market, they can contribute to aggregate movements in house prices. $^{2}$

Concentration in mortgage origination Before testing whether bank-specific mortgage supply shocks affect house price growth in U.S. regions, we have to check whether the necessary condition for granular effects from the mortgage market is fulfilled. To that goal, the dispersion of the distribution of newly issued mortgages has to be high enough, such that idiosyncratic shocks do not cancel out across a large number of mortgage suppliers. A first look at the data reveals that U.S. mortgage origination is indeed dominated by large banks. Figure 2 reports mortgage origination activity of the largest banks as a fraction of total mortgage origination. For example, mortgage origination of the top $1 \%$ of banks is almost $80 \%$ of overall lending in 2007 , with the top $0.1 \%$ of banks accounting for more than $40 \%$ of total mortgage activity in 2010 , hinting at a high degree of mortgage market concentration.

- Insert Figure 2 here -

Since granular effects can emerge only if mortgage origination is extremely concentrated, we must test whether the distribution of newly issued mortgages follows a fat-tailed power law (Gabaix (2011), Proposition 2). ${ }^{3}$ This is the case if the power law coefficient of the

\footnotetext{
${ }^{2}$ For a theoretical derivation of granular effects, see Gabaix (2011), Section 2.3 .

${ }^{3}$ Note that we test whether mortgage size is power law distributed. This does not imply automatically that the shocks are power law distributed as well as in Cúrdia et al. (2014) who show that an estimation with
} 
distribution is less than one.

Following Gabaix and Ibragimov (2011), we estimate the dispersion parameter of the size distribution of newly issued mortgages for each MSA using the following regression equation

$$
\ln \left(\operatorname{Rank}_{b m}-0.5\right)=\alpha+\beta \ln \left(\mathrm{NL}_{b m}\right)+\epsilon_{b m}
$$

where $\operatorname{Rank}_{b m}$ is the rank of bank b's newly issued mortgages in MSA $m$, and $N L_{b m}$ is the corresponding volume of newly issued mortgages. $\beta$ is the power law coefficient, i.e., the parameter of interest here.

- Insert Figure 3 here -

Figure 3 illustrates the estimation results. It plots the histogram of the estimated power law coefficients for each MSA in the year 2000. All coefficients are significant at the one percent level. ${ }^{4}$ The figure reveals that all estimates are below one (also in absolute values), meaning that the distribution of newly issued mortgages is indeed extremely dispersed with infinite variance. Thus, the distribution of new mortgages follows a fat-tailed power law in all MSAs in our sample, such that the necessary condition for granular effects from the mortgage market is fulfilled. Thereby, idiosyncratic shocks can play a role for house price growth given that concentration in mortgage origination is high enough for large banks to affect the economy.

Measuring mortgage supply shocks. Table 1 provides detailed information about our data and variable definitions.

- Insert Table 1 here -

power law distributed shocks is strongly favored by the data compared to the Gaussian shock assumption using the Smets and Wouters $(2005,2007)$ DSGE model.

${ }^{4}$ The numerical estimation results are available from the authors upon request. 
To measure idiosyncratic mortgage supply shocks, we rely on HMDA data. This data set provides annual information on every newly issued mortgage loan from individual banks to individual households. To determine whether institutions are serving the housing finance needs of their local communities, the Home Mortgage Disclosure Act from 1975 requires approximately $80 \%$ of all mortgage lending institutions nationwide to disclose information about the geographic location and other characteristics of the mortgage loans they originate, like the year of application, the dollar amount of the loan, and the application outcome. Most depository institutions (commercial banks, savings associations, and credit unions) with home or branch offices in an MSA are required to report. The only exemptions are small institutions with assets of less than $\$ 35$ million for the 2006 reporting year, lenders not in the home-lending business, or those that have offices exclusively in rural areas (non-MSAs). Non-depository consumer- and mortgage-finance companies do have to report if they originate one hundred or more home purchase or home refinancing loans per year covered. Our sample includes both depository and non-depository institutions covered by the HMDA.

The HMDA data have two important advantages over bank balance sheet data that is typically used in the granularity-literature. First, they provide information about newly issued mortgages (a flow variable). In contrast, balance sheet data provide information about the stock of credits only, such that newly issued credit can only be proxied by looking at credit growth. And second, the HMDA data allow for assigning mortgages to the regions where they are supplied, something bank balance sheet data does not permit.

Exploiting the HMDA data set, we aggregate all accepted mortgage loans for each bank according to the location of the purchased property, namely by MSA. Our regression sample covers mortgages for 345 MSAs from 1990 through 2014. At least thirty banks are 
active per year in each MSA included in the sample (Table 2). ${ }^{5}$

- Insert Table 2 here -

To identify the idiosyncratic mortgage supply shocks, we take a similar approach to that of Greenstone et al. (2014) and regress the natural logarithm of the volume of newly issued mortgage credits of bank $b$ in MSA $m$ at time $t$ on a set of bank-, time-, and MSA-fixed effects

$$
\ln \left(N L_{b m t}\right)=\alpha_{b}+\beta_{t}+\gamma_{m}+\delta_{m t}+\epsilon_{b m t} .
$$

The goal is to purge bank $b$ 's new mortgages extended to MSA $m$ from all macroeconomic and common mortgage market factors. Extracting the residual from this specification yields the bank-specific mortgage lending shock at the MSA-level. While $\alpha_{b}$ purges newly issued mortgages from all time-invariant characteristics of bank $b$, like its general business model, $\beta_{t}$ controls for all time-varying factors that affect all MSAs, like common changes in credit, general funding conditions, and economic growth. To control for demand effects, we apply the approach proposed by Khwaja and Mian (2008) and define a mortgage loan as a bank-MSA pair. Since every MSA borrows from multiple banks, including an MSA-fixed effect accounts for time-invariant differences in demand by the same MSA across the different suppliers of credit. In addition, the combined MSA-and-year fixed effects, $\delta_{m t}$, account for time-varying credit demand changes across regions. Thus, our shock measure is purged from MSA-specific demand changes.

The first panel of Table 2 presents summary statistics for the mortgage origination shock $\epsilon_{b m t}$. It reveals that even if the sample mean of bank-specific mortgage supply shocks is zero, the measure takes on negative and positive values with a standard deviation of 1.7. As shown by Equation (2), positive values present positive deviations of newly

\footnotetext{
${ }^{5}$ Restricting the number of banks per MSA to a lower bound of 30 leaves the number of MSAs in the sample unchanged but drops 547 out of 2.5 million bank-MSA-year observations.
} 
issued mortgages (by bank $b$ to MSA $m$ in year $t$ ) from the conditional mean due to bank-MSA-specific events like unexpected managerial decisions on credit supply. Negative values reflect negative deviations in mortgage origination, e.g., due to idiosyncratic funding shortages.

Granularity in regional mortgage markets. To compute a measure of granular effects from the mortgage market at the MSA-level, the Banking Granular Residual (BGR), we weigh the idiosyncratic mortgage shocks from the previous section with the respective market share of each bank in the MSA. According to the theoretical considerations by Gabaix (2011) and Bremus et al. (2013) and following the econometric approach by Mondragon (2015), we aggregate these weighted shocks, in our case at the MSA level

$$
B G R_{m t}=\sum_{b=1}^{B} \frac{\mathrm{NL}_{b m, t-1}}{\mathrm{NL}_{m, t-1}} \epsilon_{b m t}
$$

where $N L_{b m, t-1} / N L_{m, t-1}$ is the lagged market share in mortgage origination of bank $b$ in MSA $m$ at year $t-1$, and $\epsilon_{b m t}$ is the contemporaneous regional mortgage supply shock of bank $b$. This yields our measure of granular effects from the mortgage market at the MSA level, which is available at annual frequency for the period 1990-2014. The higher concentration in an MSA or the larger mortgage supply shocks, the larger the value of the $B G R$ becomes.

According to the concept of granularity, we expect the effect of the $B G R$ on aggregate house price growth to be positive. If concentration in mortgage origination is high enough, the higher bank-specific shocks or concentration are - and thus the larger the $B G R$ - the stronger should be the link to aggregate house price growth.

- Insert Figure 4 here - 
To visualize the regional differences of the $B G R$, the top panel of Figure 4 plots the average BGRs for MSAs in the U.S. between 1994-2014. If any, we find a weak geographical pattern in our measure of micro-level mortgage supply shocks - high values of the $B G R$ (dark colors) tend to be more frequent in the Eastern MSAs. We find very high values for the $B G R$ for MSAs in Illinois (e.g., Champaign-Urbana, Kankakee, Rockford, and Springfield) and New York (e.g., Buffalo-Cheektowaga-Niagara Falls, Ithaca or Rochester), while MSAs in Nevada (Carson City), Utah (St. George), Delaware (Dover and Salisbury), and California (e.g., El Centro, Hanford-Corcoran, Madera and Merced) are at the bottom of the range.

\subsection{House Price Growth and Control Variables}

Our dependent variable, house price growth, is computed based on the Freddie Mac House Price Index (FMHPI), which is available for 367 MSAs over the 1975 to 2015 period. The FMHPI is based on an ever expanding database of loans purchased by Freddie Mac or Fannie Mae. It is constructed using a repeat-transactions methodology, which is an increasingly common practice in housing research (Bollerslev et al., 2016). The FMHPI index is estimated with data including transactions on one-family and townhome properties serving as collateral on loans originated between January 1, 1975 and the end of the most recent index month. Given that the original data are published at monthly frequency, we take the median to get to annual frequency. ${ }^{6}$

The bottom panel of Figure 4 shows average house price growth for MSAs in our sample between 1994 and 2014. From this graphical inspection there is even less of an indication of a pattern for house price growth across the U.S. than for the BGRs (see top panel of Figure 4). In terms of house price growth, we find that the top three MSAs are in North

\footnotetext{
${ }^{6}$ Taking the mean of monthly house prices does not change our results qualitatively or quantitatively. If anything, it only increases the significance of our results.
} 
Carolina (Asheville), Texas (Austin-Round Rock), and Oregon (Bend-Redmond) while MSAs with the lowest house price growth in our sample are in Michigan (Ann Arbor), Massachusetts (Barnstable Town), and Connecticut (Bridgeport-Stamford-Norwalk).

A set of control variables at the MSA-level is included in the regression model for house price growth presented below. Following Favara and Imbs (2015), we include per capita personal income growth, population growth, and total full- and part-time employment, as well as the first lags of all controls. These data are available for 382 MSAs from the Bureau of Economic Analysis (BEA). Information on housing supply elasticities for each MSA is available from Saiz (2010). The elasticities are based on the amount of land that can be developed in each MSAs. This is motivated by the observation that most regions where housing supply is inelastic are strongly land-constrained for topographic reasons.

\subsection{Do Idiosyncratic Mortgage Supply Shocks Affect House Price Move- ments?}

We now turn to the link between idiosyncratic mortgage supply shocks and house price growth at the MSA-level. In order to analyze whether micro-level mortgage supply shocks have aggregate effects on house prices in U.S. regions, we run the following regression model

$$
\widehat{H P}_{m t}=\lambda_{m}+\gamma_{t}+\beta B G R_{m t}+\Gamma X_{m t}+\epsilon_{m t},
$$

where standard errors are clustered at the MSA level. $\widehat{H P}_{m t}$ is annual house price growth computed by the log-difference of the house price index described above. To control for region-specific differences in house prices as well as common time trends that affect house prices in all MSAs, a set of regional $\left(\lambda_{m}\right)$ and time fixed effects $\left(\gamma_{t}\right)$ is included 
in each regression. $B G R_{m t}$ is the banking granular residual, and $X_{m t}$ includes a set of the time-varying MSA-specific control variables. It is well known that house prices display considerable geographic heterogeneity in the U.S. (Ferreira and Gyourko, 2011). Such heterogeneity can arise from the demand side of the market, simply because income, demographic factors, and amenities are geographically heterogeneous (Lamont and Stein, 1999; Gyourko et al., 2013; Glaeser and Gyourko, 2007; Glaeser et al., 2008; Favara and Song, 2014). We follow Favara and Imbs (2015) and include per capita personal income growth, population growth, and employment here.

Yet, house price developments across regions can also be the result of differences in housing supply elasticities, for instance because of local costs, land use regulation, or geographical restrictions (Gyourko and Saiz, 2006; Gyourko et al., 2008; Saiz, 2010). To investigate how housing supply elasticities affect the link between idiosyncratic mortgage supply shocks and house price growth, we include an interaction term between the $B G R$ and the housing supply elasticity at the regional level, $H S E_{m}$, such that the regression model becomes

$$
\widehat{H P}_{m t}=\lambda_{m}+\gamma_{t}+\beta_{1} B G R_{m t}+\beta_{2} B G R_{m t} \times H S E_{m}+\Gamma X_{m t}+\epsilon_{m t} .
$$

Note that the individual effect of the housing supply elasticity is absorbed by the MSA-fixed effects $\lambda_{m}$, given that our elasticity measure is time-invariant. Based on the analyses of Favara and Imbs (2015), the idea is that changes in mortgage supply impact housing demand, which in turn affects house prices - and this the more so the lower is the elasticity of housing supply. Put differently, the more limited is the reaction of housing supply to changes in demand, the stronger the adjustment in prices should be. Hence, we expect $\beta_{2}$ to be negative. 


\section{Results}

Idiosyncratic mortgage supply shocks and house price growth Table 3 provides our baseline regression results. It reveals that bank-specific shocks at the MSA-level, as measured by the $B G R$, are positively linked to house price growth. In Column (1) we find a positive and statistically significant effect of the $B G R$ on house price growth, meaning that positive innovations to mortgage origination at the level of individual large banks lead to higher house price growth. Vice versa, negative bank-specific mortgage supply shocks reduce house price growth. Thus, our results provide evidence for granular effects from the U.S. mortgage lending sector at the regional level. The more concentrated the mortgage market is, the easier do bank-level shocks spread across the housing market.

All control variables have the expected positive effects on house price growth: the higher income, population and employment growth is in an MSA, the higher is the demand for housing, and the higher rents tend to be. This, in turn, fosters house price growth.

Quantitatively, the estimated coefficient in column (1) reveals that an increase in the $B G R$ by one standard deviation (0.72) leads to an increase in MSA-level house price growth by 0.7 percentage points. Put differently, variation in bank-specific mortgage supply explains about $10 \%$ of the variation in house price growth at the MSA-level. ${ }^{7}$ Thus, the economic significance of the $B G R$ is comparable in size to the control variables: while contemporaneous employment growth also explains about $10 \%$ of house price growth at the MSA-level, income growth matters somewhat more with a normalized beta-coefficient of 0.26 .

Overall, column (1) supports the expectation that idiosyncratic changes in mortgage lending positively impact house price growth at the MSA level both in terms of statistical

\footnotetext{
${ }^{7}$ This quantification is based on the normalized beta-coefficient that is obtained by multiplying the estimated coefficient of interest with the standard deviation of the corresponding regressor (here: the $B G R$ ) and dividing by the standard deviation of the dependent variable (house price growth).
} 
and economic significance. Hence, given that concentration in mortgage origination is very high, meaning that a few banks dominate the market, we conclude that idiosyncratic shocks to mortgage supply have aggregate affects at the housing market.

- Insert Table 3 here -

Our result is in line with both theory and empirical research. Theoretical papers (Gabaix, 2011; Bremus et al., 2013) predict a role of idiosyncratic shocks for aggregate outcomes if market concentration is high. The empirical literature confirms a positive relationship between idiosyncratic, bank-specific, shocks and aggregate outcomes. Amiti and Weinstein (2016) demonstrate a significant role of granular shocks to the banking system for the macroeconomy in Japan. In their case, granular effects from banking explain roughly $40 \%$ of the variation in aggregate investment. Buch and Neugebauer (2011) also find a positive impact of the $B G R$ on short-run GDP growth, explaining $16 \%$ of the short-run, cyclical variation in per capita GDP growth within a given country. Bremus and Buch (2016) establish that 5-16\% of the variation in GDP per capita growth in a panel of 79 countries can be attributed to bank-specific shocks to asset growth due to granular effects.

The elasticity of housing supply. Having established a positive link between microlevel mortgage shocks and regional house price growth on average, following the literature (Gyourko and Saiz, 2006; Gyourko et al., 2008; Saiz, 2010), we now investigate how the housing supply elasticity affects the relation between idiosyncratic mortgage supply shocks and house prices at the MSA level. Based on a standard supply-demand schedule, we expect the effect of bank-specific mortgage supply shocks to have more pronounced effects on house prices the less elastic is housing supply. To test this hypothesis, column (2) of Table 3 provides regression results for Equation (5). It shows, first, that the $B G R$ retains 
its positive and statistically significant effect on house price growth. Second, the interaction effect with the housing supply elasticity is negative, as expected, and statistically significant, thus indicating that granular effects from the mortgage market on house prices are weaker the more elastic housing supply becomes.

Figure 5 illustrates the marginal effect of the $B G R$ on house price growth, conditional on the elasticity of housing supply (based on Table 3, column (2)). It reveals that idiosyncratic mortgage supply shocks affect house price growth only if housing supply is relatively inelastic, for example in regions in which supply extension is geographically limited, like in the Rocky Mountains. In contrast, in regions in which supply can react more easily to changes in housing demand, price changes resulting from idiosyncratic mortgage supply shocks are weaker and eventually disappear.

- Insert Figure 5 here -

The financial crisis of 2007-09. Column (3) of Table 3 investigates how the financial crisis of 2007-09 impacts our baseline results. To alleviate concerns about crisis-driven effects, we augment Equation (4) to include a crisis dummy that equals one for the years 2007 to 2009 and zero otherwise, as well as its interaction with the $B G R$. The results in column (3) highlight that the crisis dummy has a negative and statistically significant effect on house price growth, which is not surprising as house prices have been depressed during the crisis years. However, the granular effect from the mortgage market, as measured by the $B G R$, remains intact. Furthermore, interacting the crisis dummy with the $B G R$ reveals stronger granular effects from the mortgage market on house price growth during the crisis. That is, bank-specific mortgage supply shocks affect house price dynamics even more in times of distress. 
Market concentration. As pointed out above, granular effects should be more pronounced in areas with a higher market concentration, which we investigate by expanding Equation (4) with a Herfindahl-Hirschman index (HHI) and its interaction with the BGR. The HHI is based on the volume of newly issued mortgages and therefore captures concentration in mortgage origination. Indeed, column (4) of Table 3 indicates that MSAs with higher mortgage market concentration show a closer link between the $B G R$ and house price changes. Figure 6 displays the marginal effect of the $B G R$ on house price growth conditional on the mortgage market HHI. In accordance with column (4) of Table 3, the marginal effect of $B G R$ on house price growth is becoming stronger with increasing mortgage market concentration. Hence, our results seem to point in the same direction as recent findings by Akins et al. (2016) who show that U.S. states that have less competitive banking markets experienced - among others - a much higher growth in house prices before the crisis of 2007-09.

- Insert Figure 6 here -

Robustness Our results are robust against different sanity checks. First, the positive link between the $B G R$ and house price growth remains significant if we exclude all control variables or fixed effects from Equation (4). As shown in Table 4, the positive and significant effect of the $B G R$ on house price growth is more pronounced when we use no other timeand MSA-varying control variables but MSA and time fixed effects (columns (7) and (5)). If we include both sets of fixed effects separately and add the other control variables (columns (4) and (6)), we even find a smaller effect of the $B G R$ than in our baseline regression with the full set of controls. This may provide evidence that the effects in our sample are affected differently by region and time fixed effects, thus making the fully-specified model that we estimate via Equation (4) most credible. 
- Insert Table 4 here -

In addition, the effect of the $B G R$ presented in column (1) of Table 3 remains intact for different shock specifications of Equation (2). As shown in the second column of Table 5, we find a positive and significant effect of the $B G R$ on house price growth if shocks are calculated with bank, bank-time, year, and MSA fixed effects. Given that all time varying and time constant bank-heterogeneity is "filtered" out, it is not surprising that in this specification the impact of the $B G R$ is smallest; the idiosyncratic supply shocks just reflect the variation of mortgage supply across MSAs for each bank in this case. The most parsimonious measure of the $B G R$ (column (3)) is based on a shock specification that includes only year, MSA and year-MSA fixed effects. It indicates the largest effect of all different specifications of the $B G R$. This is plausible since the variation in mortgage lending driven by (time-invariant and -variant) heterogeneity at the bank-level is contained in the shocks. Column (4) of Table 5 shows an insignificant effect of the $B G R$ on house prices based on a lavish shock specification: bank, MSA, time, bank-time and MSA-time fixed effects. Possibly, there is too little variation left over in the shock measure and, thus, in the $B G R$.

- Insert Table 5 here -

\subsection{Threats to Validity}

One concern regarding internal validity relates to the exogeneity of the $B G R$. According to Flannery and Lin (2016), it is very difficult to identify the causal effect between credit and house prices since the direction of causality could go both ways. House prices may rise in reaction to an increase in credit supply via cheaper and more plentiful mortgage lending. But house prices may also encourage further lending because higher real estate values serve as collateral and thus increase borrowing capacities. 
If we identified idiosyncratic movements of mortgage lending correctly, by definition, it is very unlikely that these idiosyncratic shocks are correlated with other confounding factors as we clean the shock measure from all MSA-time variation $\left(\delta_{m t}\right)$. However, we follow Favara and Imbs (2015) and address this issue with an instrumental variable approach as we cannot fully control for demand effects at the bank-household level. To instrument the $B G R$, we use a deregulation event in U.S. banking markets.

For the instrumental variable (IV) estimation, we make use of the fact that in the past decades, the U.S. banking sector went through regulatory changes regarding banks' geographic expansion (Kroszner and Strahan, 1999). After the deregulation event of the Interstate Banking and Branching Efficiency Act (IBBEA) in 1994, banks could operate across state borders without any formal authorization from state authorities. Even though it was fully legal after the IBBEA to branch across states, U.S. states were left with the possibility of putting limits on interstate branching. ${ }^{8}$ Rice and Strahan (2010) generate a time varying index that records these interstate branching restrictions. Their index captures the period from 1994 to 2005 and takes values between 0 and 4 while zero indicates the least restricted states and four the most restricted states. We reverse the index so that high values refer to deregulated states and we use it as an instrument for the $B G R$.

The idea behind this instrument is that it affects the $B G R$ via increased entry into the mortgage market, but at the same time being independent of house prices. Ex ante, we would hypothesize a negative link between deregulation and the Banking Granular Residual since a deregulated market should increase entry and, hence, lower the market shares of the incumbent lenders. ${ }^{9}$ The first stage of the Two-Stage-Least-Squares IV-estimation model

\footnotetext{
${ }^{8}$ For example, some states allowed de novo branching, whereby banks could open new branches anywhere within state borders, and others did not. There is also a large variation between states that enacted statewide deposit caps on branch acquisitions. According to the IBBEA, out of state branching became de jure possible. However, the Rice and Strahan (2010) index captures the de facto restrictions.

${ }^{9}$ The imposed exogeneity of the instrument should reduce concerns of omitted variable bias and reverse causality. One objection might be that bank lobbyists or consumer protectionists anticipate increasing mortgage demand and motivate politicians to deregulate. The causal chain would run the other way:
} 
is the following

$$
B G R_{m t}=\lambda_{m}+\gamma_{t}+\beta_{1} D R E G_{s t-1}+\Gamma X_{m t}+\epsilon_{m t} .
$$

$D R E G$ is the reverse deregulation index from Rice and Strahan (2010) lagged by one year. It ranges between zero (most restrictive states) and four (least restrictive states). In the second stage, we regress house price growth on the predicted $B G R$ values from Equation (6).

Regarding the relevance assumption of the instrument, column (2) of Table 6 reports results for the first stage regression. We find that the deregulation index negatively and significantly affects the $B G R$. States that deregulated more have a lower BGR: more entry reduces the impact of idiosyncratic shocks on the aggregate economy because the market structure changes. The first stage F-statistic on the excluded instruments yields 13.80 $(\mathrm{p}$-value $=0.0003)$, which is above the recommended F-statistic of 10 and diminshes worries about weak instruments.

The second stage regression in our analysis,

$$
\widehat{H P}_{m t}=\lambda_{m}+\gamma_{t}+\delta_{1} B G R_{m t}^{\text {predicted }}+\Gamma X_{m t}+\epsilon_{m t},
$$

then uses the predicted values for the $B G R$ from Equation (6), which should be free of any potential remaining endogenous variation. The corresponding results in column (1), Table 6 reveal that the part of the BGR that can be explained by branching deregulation has substantial explanatory power for house price growth between 1994 and 2005. In this setup, an increase of the $B G R$ by one standard deviation leads to an economically meaningful

mortgage demand would trigger deregulation. However, this seems unlikely since Favara and Imbs (2015) show that unaffected banks, due to their legal status such as independent mortgage lenders, thrifts or credit unions should have taken advantage of such hypothetical boom as well as depository institutions. In fact, they did not. 
rise in house price growth by $113 \%$ of its standard deviation. ${ }^{10}$

- Insert Table 6 here -

Our IV analysis corroborates our previous results of a positive and significant effect of the $B G R$ on house price growth. Regarding the relevance of our instrument, we provide evidence that the deregulation index has a significant impact on the $B G R$ in a regression of Equation (6). Even though the F-test from the first stage shows that our instrument seems strong enough, the question whether the instrument fulfills the exclusion restriction remains open. To provide some evidence on that front, we re-run the IV regression for states that have deregulated their banking markets only weakly. In a similar way to Angrist et al. (2010), ${ }^{11}$ we assume that for those states the instrument should have a lesser impact on the $B G R$ than for states that have deregulated more. We find that if we use only states with a low deregulation index (values equal to 0 or 1 ) the coefficient of the $B G R$ turns insignificant in the second stage of our instrumental variable regression (column (3), Table 6). More importantly, we provide evidence that the significant impact of the instrument on the $B G R$ vanishes in the first stage as shown in column (4) of Table 6 . Moreover, the reduced form coefficient for the instrument is also insignificant (Column (5)), which indicates that there are no bypassing effects of the deregulation index on house price growth. We interpret this as affirmative for the exclusion restriction of our instrument. ${ }^{12}$

\footnotetext{
${ }^{10}$ This calculation is based on summary statistics of the IV regression sample with 243 MSAs between 1994-2005.

${ }^{11}$ They analyze whether family size affects the performance of first borns, and use the occurrence of twins and the sex of the second borns as instruments. To show that the exclusion restriction holds they investigate their results for samples that include only never takers (highly educated women) or always takers (women from African ethnicity) as the instrument. They argue that for the exclusion restriction to hold the coefficients for the instruments in the first stage and in the reduced form must be insignificant.

${ }^{12}$ We find the same results when we include states with an index between 0 and 2 . If we further expand the sample to states with index values between 0 and 3, we find the same results as in column (1) and (2) of Table 6.
} 


\subsection{Persistence of Granular Effects From the Mortgage Market}

Since, so far, we only show the impact response of house price growth to idiosyncratic mortgage supply shocks, we now investigate the dynamic responses to see how persistent is the effect of the $B G R$ on house price growth. To make this plausible, we follow Favara and Imbs (2015) and use the local projection methodology by Jorda (2005). It sequentially regresses house price growth shifted forward by one period on the $B G R$ and on the control variables. The resulting impulse responses are based on a vector of estimates $\beta_{1}^{i}$ at horizon $i=0, \ldots, 6$ collected from the baseline regression of Equation (4)

$$
\widehat{H P}_{m t+1}=\lambda_{m}+\gamma_{t}+\widehat{H P}_{m t-1}+\beta_{1}^{i} B G R_{m t}+\Gamma X_{m t}+\epsilon_{m t}
$$

and from the IV panel regression of Equation (7)

$$
\widehat{H P}_{m t+1}=\lambda_{m}+\gamma_{t}+\widehat{H P}_{m t-1}+\beta_{1}^{i} B G R_{m t}^{\text {predicted }}+\Gamma X_{m t}+\epsilon_{m t}
$$

Panel A of Figure 7 shows fairly persistent effects of the $B G R$ on house price growth in the baseline regression. The effect peaks after 1-2 years, peters down and loses significance after four years. This result is attenuated by the impulse response function based on the IV specification.

- Insert Figure 7 here -

Panel B reveals that the granular effect on house price growth is less persistent over time. The effect peaks directly after the shock and becomes insignificant after two years. These more conservative results seem to be in line with previous literature. For example, Favara and Imbs (2015) demonstrate that the response of house price growth to an exogenous common credit supply shock is long-lived since it fades out after five to six years. The 
focus on a common supply shock might justify the substantial magnitude of their estimated effect compared to our idiosyncratic shock measure. Since we investigate idiosyncratic supply shocks, the fading out of our IV regression effects after two years seems reasonable.

\section{Conclusions}

This paper highlights the importance of mortgage market concentration for the propagation of idiosyncratic bank events and their effect on house price growth. Our analysis of granular effects from the U.S. mortgage market yields four key findings. First, mortgage origination at the MSA-level is highly concentrated. The distribution of newly issued mortgages follows a fat-tailed power law, meaning that a small number of players dominate mortgage origination. Second, idiosyncratic mortgage supply shocks are a driver of house price growth. The larger the increase in mortgage supply due to bank-specific events is, the faster house prices grow. These results are robust to several alternative model specifications. Third, we find that more inelastic housing supply aggravates the effect of bank-specific mortgage supply shocks on house prices. Fourth, the effect of idiosyncratic shocks at the regional level is rather short-lived when we consider our conservative instrumental variable regression results. We find that the granular effects from the mortgage market die out after two years. This augments the findings from previous literature that the impact of common shocks is very persistent.

The results are important for informing the debate on the treatment of large financial institutions, since we show that bank-specific shocks like financial innovations, fine payments, computer glitches, or unexpected managerial decisions happening to banks with large market shares have effects beyond the micro-level. The higher mortgage market concentration, the easier do micro-level events spread across housing markets. Hence, in addition to indicators like mortgage growth and loan-to-value ratios, macroprudential regulation 
should take market shares and mortgage market concentration into account when analyzing macroeconomic stability. 


\section{References}

Adelino, M., Schoar, A., Severino, F., 2012. Credit Supply and House Prices: Evidence from Mortgage Market Segmentation. NBER Working paper No. 17832.

Akins, B., Li, L., Ng, J., Rusticus, T. O., 2016. Bank competition and financial stability: evidence from the financial crisis. Journal of Financial and Quantitative Analysis 51, $1-28$.

Allen, F., Gale, D., 2007. Understanding Financial Crisis. Clarendon Lecture in Finance.

Amiti, M., Weinstein, D. E., 2016. How Much do Bank Shocks Affect Investment? Evidence from Matched Bank-Firm Loan Data. Journal of Political Economy, forthcoming.

Angrist, J., Lavy, V., Schlosser, A., 2010. Multiple experiments for the causal link between the quantity and quality of children. Journal of Labor Economics 28, 773-824.

Blank, S., Buch, C. M., Neugebauer, K., 2009. Shocks at large banks and banking sector distress: The Banking Granular Residual. Journal of Financial Stability 5, 353-373.

Bollerslev, T., Patton, A., Wang, W., 2016. Daily house price indices: Construction, modeling, and longer-run predictions. Journal of Applied Econometrics 31, 1005-10025.

Bremus, F., Buch, C. M., 2016. Granularity in banking and growth: Does financial openness matter? Journal of Banking \& Finance, forthcoming.

Bremus, F., Buch, C. M., Russ, K., Schnitzer, M., 2013. Big banks and macroeconomic outcomes: Theory and cross-country evidence of granularity. NBER Working paper No. 19093, 1-40.

Buch, C. M., Neugebauer, K., 2011. Bank-specific shocks and the real economy. Journal of Banking \& Finance 35, 2179-2187. 
Cúrdia, V., Negro, M., Greenwald, D. L., 2014. Rare shocks, great recessions. Journal of Applied Econometrics 29, 1031-1052.

Di Giovanni, J., Levchenko, A., Ranciere, R., 2011. Power laws in firm size and openness to trade: Measurement and implications. Journal of International Economics 85, 42-52.

Di Maggio, M., Kermani, A., 2016. Credit-Induced Boom and Bust. The Review of Financial Studies, forthcoming 14-23.

Favara, G., Imbs, J., 2015. Credit Supply and the Price of Housing. American Economic Review 105, 958-92.

Favara, G., Song, Z., 2014. House price dynamics with dispersed information. Journal of Economic Theory 149, 350-382.

Ferreira, F., Gyourko, J., August 2011. Anatomy of the beginning of the housing boom: US neighborhoods and metropolitan areas, 1993-2009. NBER Working Paper No. 17374.

Flannery, M. J., Lin, L., 2016. House prices, bank balance sheets, and bank credit supply. Working paper.

Gabaix, X., 2011. The granular origins of aggregate fluctuations. Econometrica 79, 733-772.

Gabaix, X., Ibragimov, R., 2011. Rank - 1/2: a simple way to improve the OLS estimation of tail exponents. Journal of Business \& Economic Statistics 29, 24-39.

Glaeser, E. L., Gyourko, J., 2007. Arbitrage in housing markets. Tech. rep., National Bureau of Economic Research.

Glaeser, E. L., Gyourko, J., Saiz, A., 2008. Housing supply and housing bubbles. Journal of Urban Economics 64, 198-217. 
Greenstone, M., Mas, A., Nguyen, H.-L., 2014. Do Credit Market Shocks Affect the Real Economy? Quasi-Experimental Evidence from the Great Recession and Normal Times. NBER Working paper No. 20704, 1-45.

Gyourko, J., Mayer, C., Sinai, T., 2013. Superstar Cities. American Economic Journal: Economic Policy 5, 167-99.

Gyourko, J., Saiz, A., 2006. Construction costs and the supply of housing structure. Journal of Regional Science 46, 661-680.

Gyourko, J., Saiz, A., Summers, A., 2008. A new measure of the local regulatory environment for housing markets: The Wharton Residential Land Use Regulatory Index. Urban Studies $45,693-729$.

Jorda, O., 2005. Estimation and Inference of Impulse Responses by Local Projections. American Economic Review 95, 161-182.

Jorda, O., Schularick, M., Taylor, A. M., 2016. The great mortgaging: housing finance, crises and business cycles. Economic Policy 31, 107-152.

Justiniano, A., Primiceri, G. E., Tambalotti, A., January 2015. Credit supply and the housing boom. NBER Working Paper No. 20874.

Khwaja, A. I., Mian, A., 2008. Tracing the Impact of Bank Liquidity Shocks: Evidence from an Emerging Market. American Economic Review 98, 1413-42.

Kindleberger, C. P., 1978. Manias, Panics, and Crashes: A History of Financial Crises, 1st Edition. Basic Books.

Kroszner, R., Strahan, P. E., 1999. What Drives Deregulation? Economics and Politics of the Relaxation of Bank Branching Restrictions. Quarterly Journal of Economics 114, 1437-1467. 
Lamont, O., Stein, J. C., 1999. Leverage and house-price dynamics in US cities. RAND Journal of Economics 30, 498-514.

Landier, A., Sraer, D., Thesmar, D., 2016. Banking integration and house price comovement. Journal of Financial Economics, forthcoming.

Loutskina, E., Strahan, P. E., 2015. Financial integration, housing, and economic volatility. Journal of Financial Economics 115, 25-41.

Mian, A., Sufi, A., 2009. The Consequences of Mortgage Credit Expansion: Evidence from the U.S. Mortgage Default Crisis. Quarterly Journal of Economics 124, 1449-1496.

Mian, A., Sufi, A., 2014. House of Debt: How They (and You) Caused the Great Recession, and How We Can Prevent It from Happening Again. Chicago Press.

Mondragon, J., 2015. Household Credit and Employment in the Great Recession. Job Market Paper, 1-82.

Rice, T., Strahan, P. E., 2010. Does Credit Competition Affect Small-Firm Finance? The Journal of Finance 65, 861-889.

Saiz, A., 2010. The geographic determinants of housing supply. Quarterly Journal of Economics 125, 1253-1296.

Smets, F., Wouters, R., 2005. Comparing shocks and frictions in US and euro area business cycles: a Bayesian DSGE approach. Journal of Applied Econometrics 20, 161-183.

Smets, F., Wouters, R., 2007. Shocks and frictions in US business cycles: A Bayesian DSGE approach. The American Economic Review 97, 586-606. 


\section{Figures and Tables}

Figure 1: U.S. mortgage loans to total loans

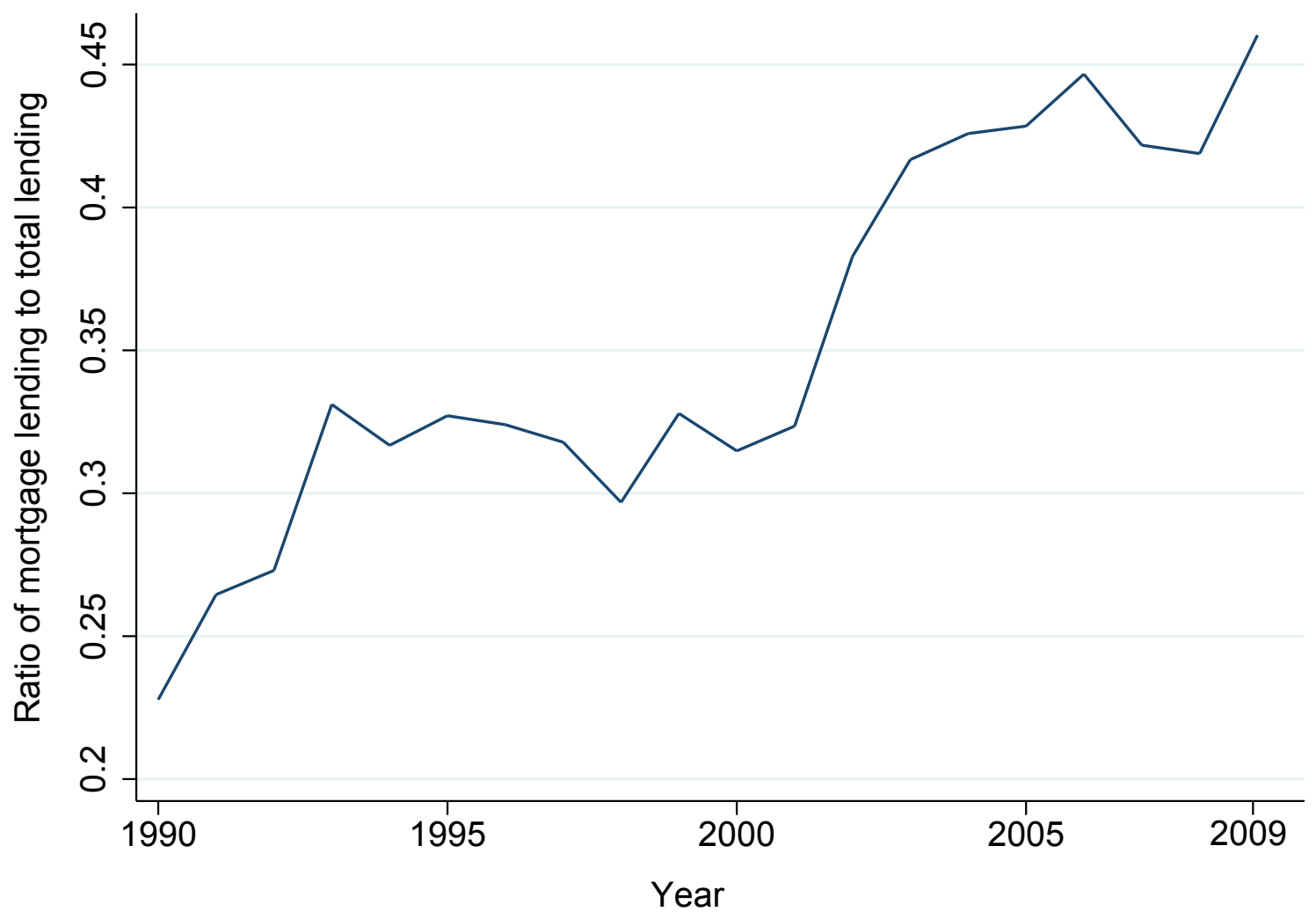

Notes: This figure plots the ratio of mortgages to total loans for the period 1990-2009. Mortgages are defined as the total stock of 1-4 family and 5+ (multifamily) real estate mortgages. Total loans are measured as aggregate gross book value of total loans (before deduction of valuation reserves). The Call Reports data cover all banks regulated by the FRS, FDIC, and the OCC. 
Figure 2: Mortgage lending of the largest banks to total mortgage lending

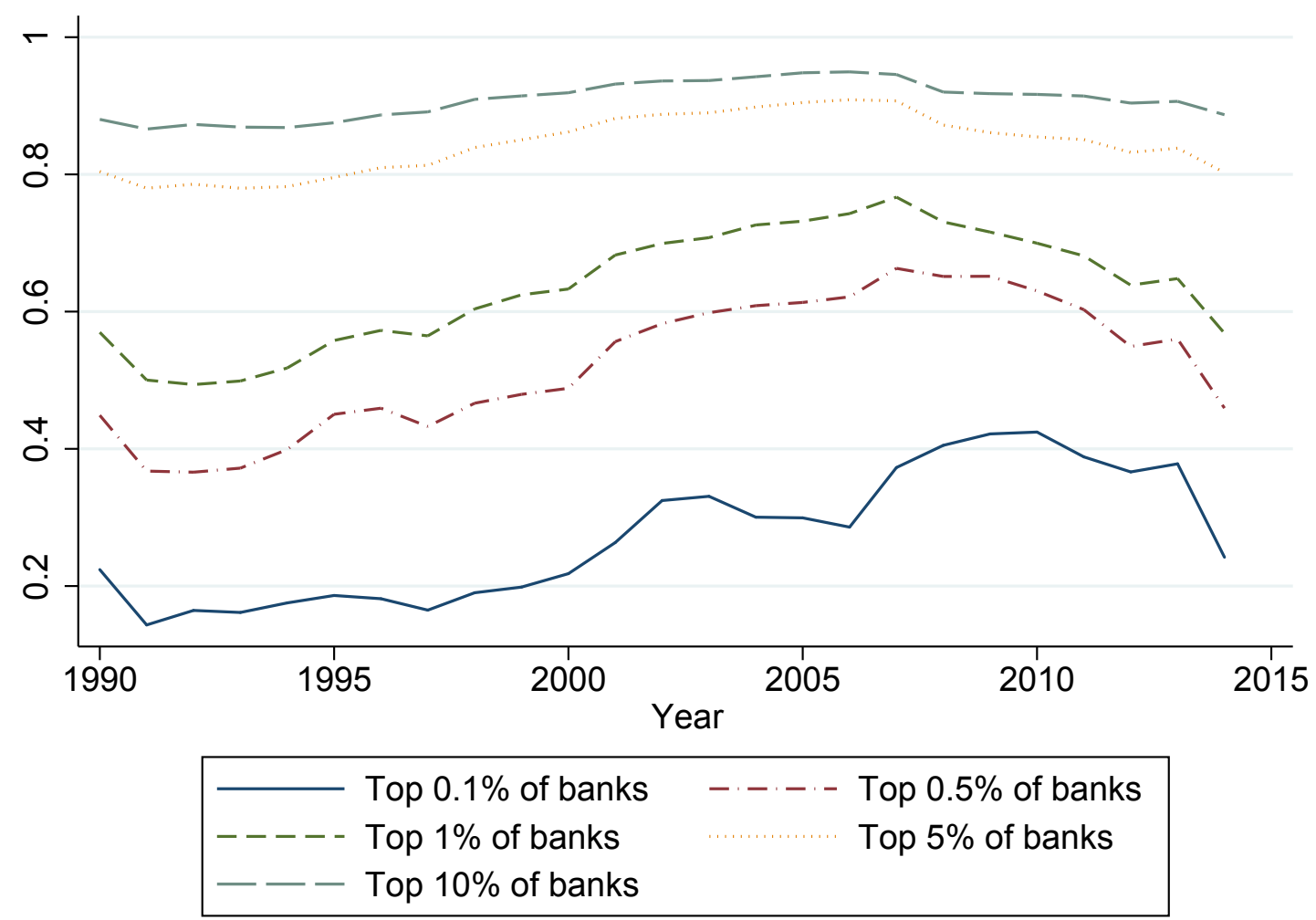

Notes: This figure illustrates the sum of newly issued mortgages for the top $0.1 \%, 0.5 \%$, $1 \%, 5 \%$ and $10 \%$ of banks aggregated at the U.S. level, as a fraction of total newly issued mortgages of all banks over the period 1990-2014. The total average number of banks each year is 7900 comprising both depository and non-depository institutions. The average number of banks in the top $10 \%$ is 800 . The HMDA data cover $80 \%$ of bank home lending activity nationwide. 
Figure 3: Histogram of estimated power law coefficients of the mortgage size distribution

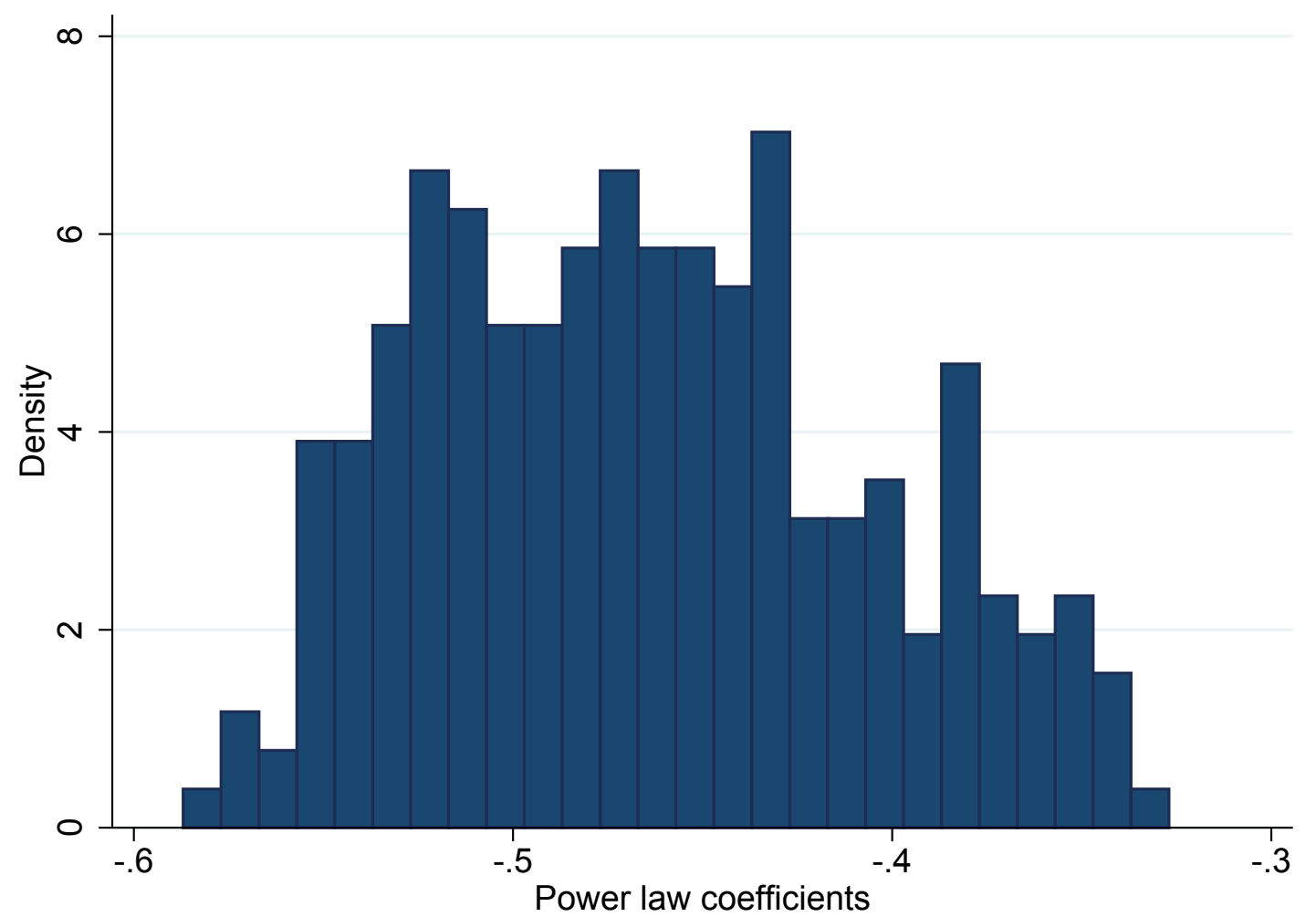

Notes: This graph shows the histogram of power law coefficients of the distribution of newly issued mortgages loans per MSA in the year 2000. Following Gabaix and Ibragimov (2011), for each of the 345 MSAs we regress the log of banks' rank (based on newly issued mortgages) on the log of their newly issued mortgages. The resulting coefficient indicates whether the bank size distribution in each MSA market follows a fat-tailed power law. This is the case if the absolute value is below one. 
Figure 4: Regional variation in mortgage market granularity and house price growth

\section{Granularity in the mortgage market (1990-2014, average)}
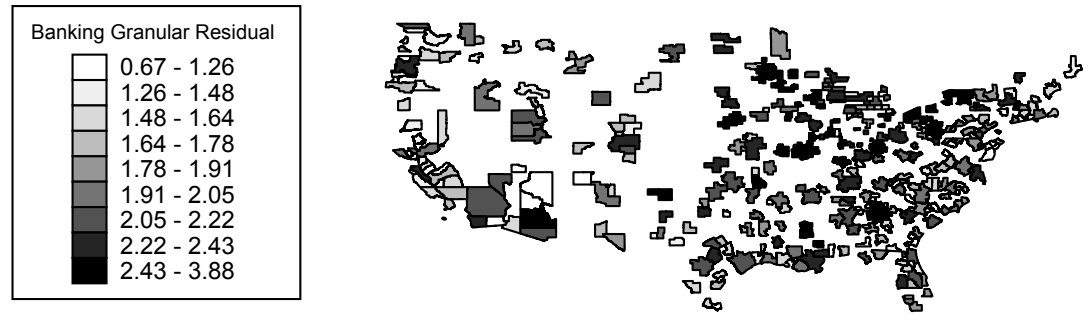

House price growth (1990-2014, average)
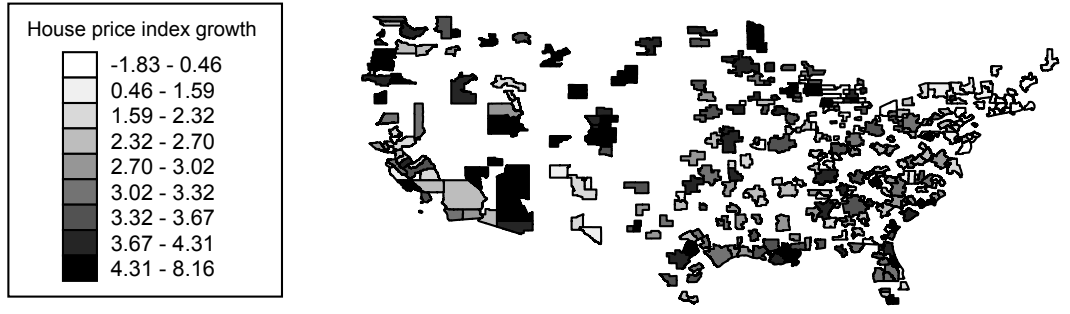

Notes: This figure depicts the averaged Banking Granular Residual (upper subgraph) over the period 1990-2014 across all 345 MSAs in our sample and the average house price index growth (lower subgraph) over the same period for all MSAs in the sample. 
Figure 5: Marginal effects of the $B G R$ depending on housing supply elasticity

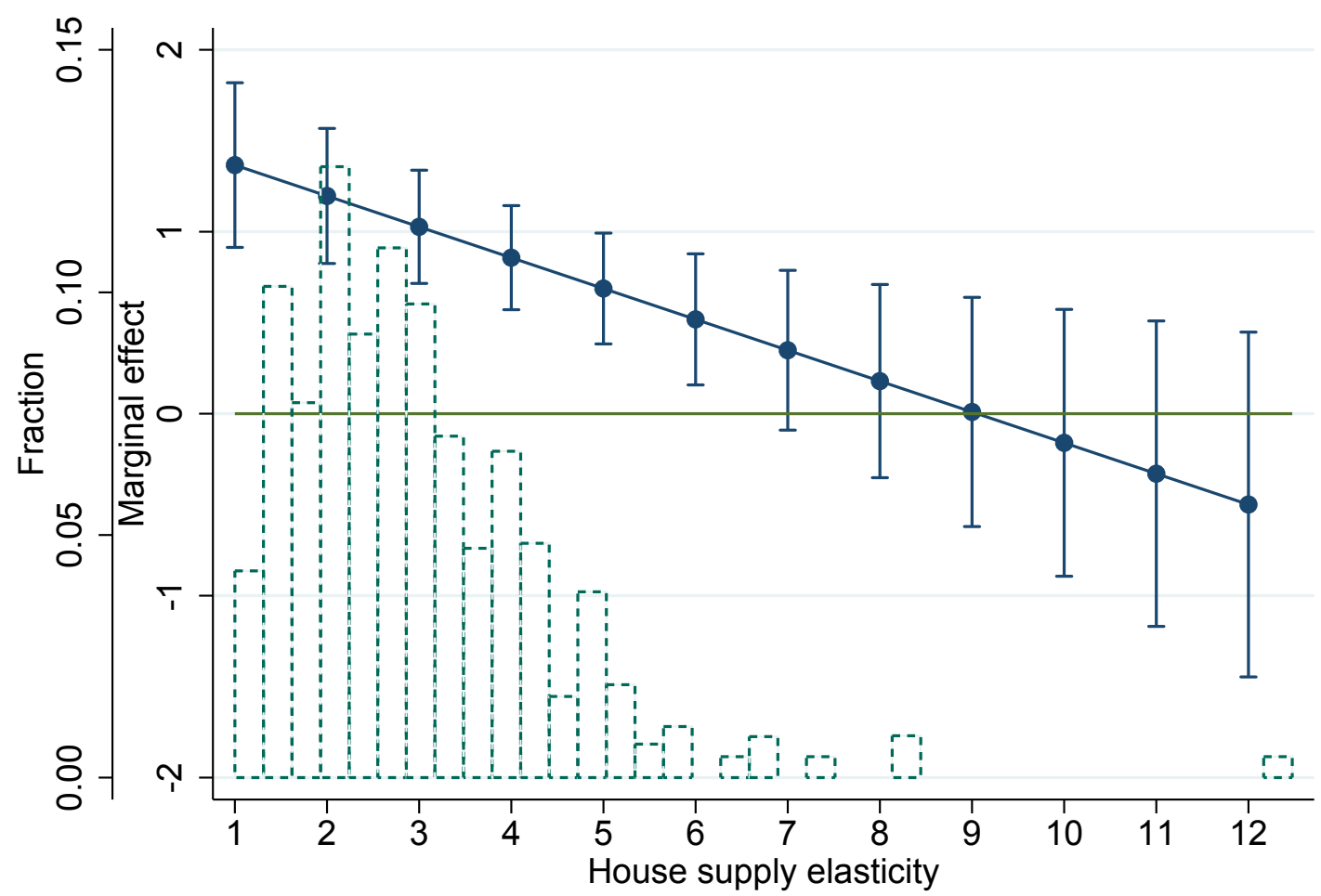

Notes: This graph shows the average marginal effect of the Banking Granular Residual on house price growth conditional on Saiz's Index of Housing Supply Elasticity (Saiz, 2010). The estimated marginal effects are denoted by dots enclosed by $95 \%$ confidence bands. The second Y-axis depicts the distribution of the housing supply elasticity measure. The graph is based on specification (2) of Table 3 . 
Figure 6: Marginal effects of the $B G R$ depending on mortgage market concentration

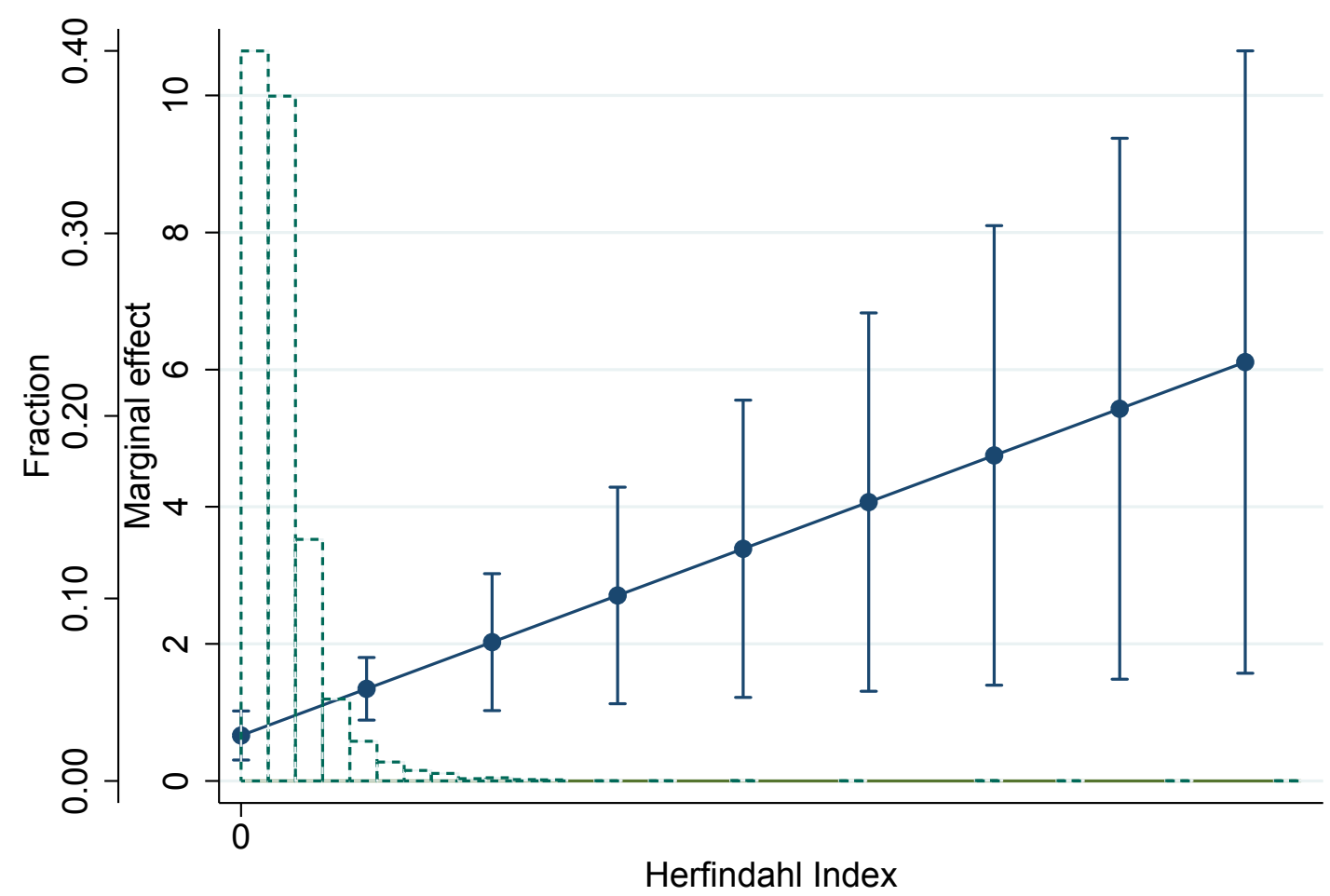

Notes: This graph shows the average marginal effect of the Banking Granular Residual on house price growth conditional on mortgage market concentration. The concentration measure is constructed by a Herfindahl index (HHI) based on newly issued mortgage loans. Higher values of the HHI indicate greater concentration. The estimated marginal effects are denoted by dots enclosed by $95 \%$ confidence bands. The second $\mathrm{Y}$-axis depicts the distribution of the HHI. The graph is based on specification (4) of Table 3. 
Figure 7: Dynamic effects of the instrumented $B G R$ on house price growth

\section{A: House price response to BGR over time}

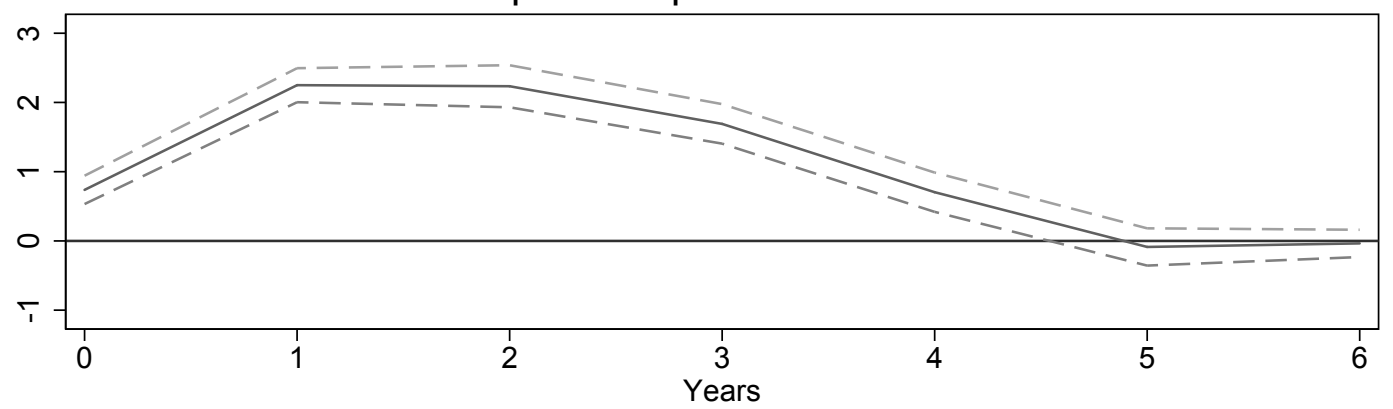

B: House price response to instrumented BGR over time

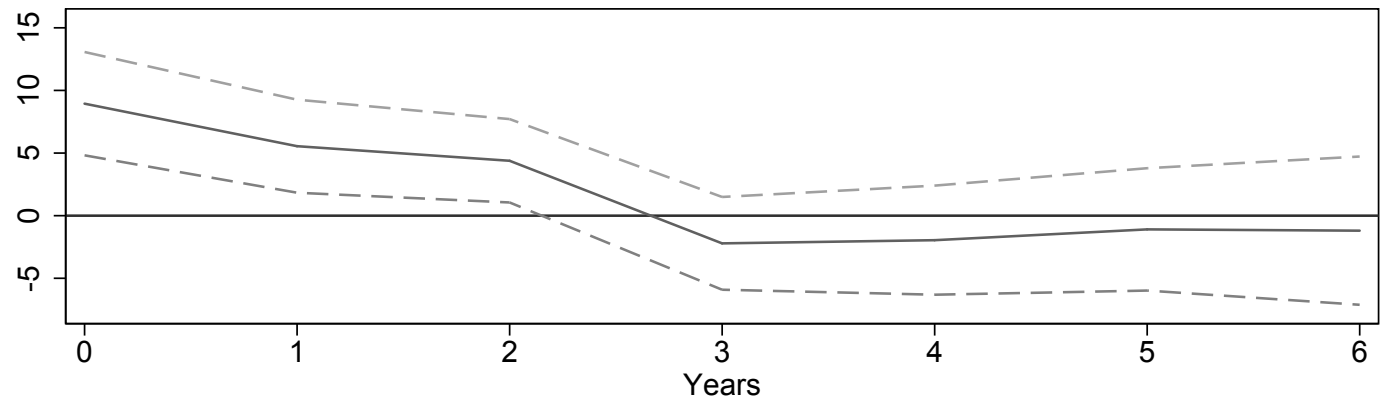

Notes: This graph shows the response of house price growth to the instrumented Banking Granular Residual over time. The impulse response function is computed with the local projection method proposed by Jorda (2005). The graph (subgraph A and B) is based on Equations (8) and (9), respectively. Dashed lines reflect $90 \%$ confidence bands. 


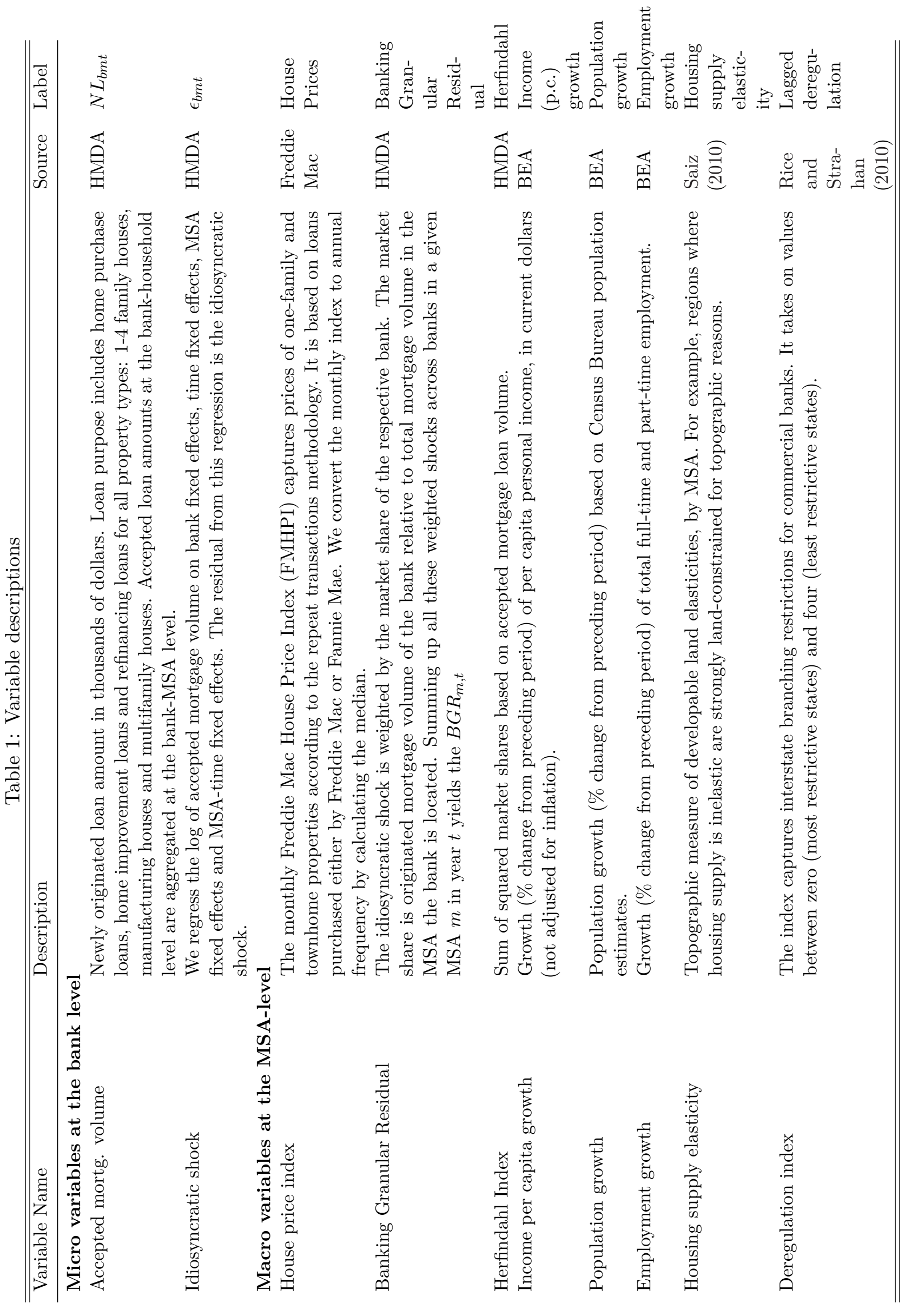




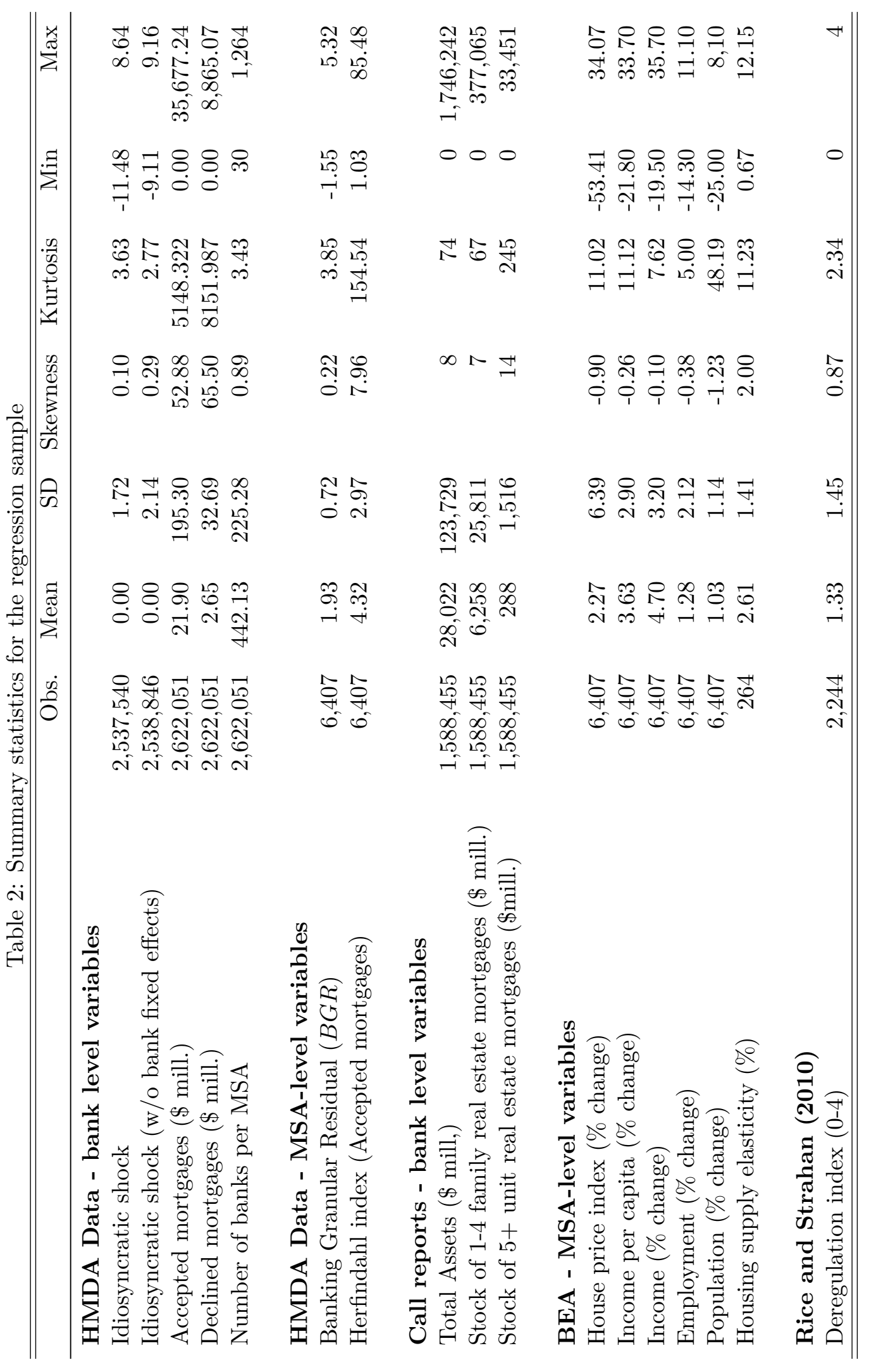


Table 3: Determinants of house price growth

\begin{tabular}{|c|c|c|c|c|}
\hline & $(1)$ & $(2)$ & $(3)$ & $(4)$ \\
\hline Banking Granular Residual & $\begin{array}{c}0.962^{\text {*** }} \\
(0.132)\end{array}$ & $\begin{array}{c}1.480^{* * *} \\
(0.262)\end{array}$ & $\begin{array}{c}0.756^{\text {**** }} \\
(0.138)\end{array}$ & $\begin{array}{c}0.594^{* * *} \\
(0.204)\end{array}$ \\
\hline Income (p.c.) growth & $\begin{array}{c}0.577^{* * *} * \\
(0.052)\end{array}$ & $\begin{array}{c}0.611^{* * *} \\
(0.059)\end{array}$ & $\begin{array}{c}0.593^{* * *} \\
(0.052)\end{array}$ & $\begin{array}{c}0.575^{* * *} \\
(0.052)\end{array}$ \\
\hline Lagged income (p.c.) growth & $\begin{array}{c}0.433^{* * *} \\
(0.039)\end{array}$ & $\begin{array}{c}0.478^{* * * *} \\
(0.046)\end{array}$ & $\begin{array}{c}0.432^{\text {**** }} \\
(0.038)\end{array}$ & $\begin{array}{c}0.432^{* * *} \\
(0.039)\end{array}$ \\
\hline Population growth & $\begin{array}{c}0.944^{* * *} \\
(0.207)\end{array}$ & $\begin{array}{c}0.948^{* * *} \\
(0.278)\end{array}$ & $\begin{array}{c}0.966^{* * *} \\
(0.209)\end{array}$ & $\begin{array}{c}0.937^{* * *} \\
(0.206)\end{array}$ \\
\hline Lagged population growth & $\begin{array}{c}0.794^{* * *} \\
(0.096)\end{array}$ & $\begin{array}{c}0.809^{* * * *} \\
(0.121)\end{array}$ & $\begin{array}{c}0.810^{* * *} \\
(0.099)\end{array}$ & $\begin{array}{c}0.791^{* * *} \\
(0.096)\end{array}$ \\
\hline Employment growth & $\begin{array}{c}0.270^{* * *} \\
(0.055)\end{array}$ & $\begin{array}{c}0.235^{* * * *} \\
(0.062)\end{array}$ & $\begin{array}{c}0.245^{* * *} \\
(0.057)\end{array}$ & $\begin{array}{c}0.273^{* * *} \\
(0.055)\end{array}$ \\
\hline Lagged employment growth & $\begin{array}{c}0.152^{* * *} \\
(0.047)\end{array}$ & $\begin{array}{c}0.167^{* * * *} \\
(0.054)\end{array}$ & $\begin{array}{c}0.141^{* * *} \\
(0.047)\end{array}$ & $\begin{array}{c}0.151^{* * *} \\
(0.047)\end{array}$ \\
\hline BGR x Housing supply elasticity & & $\begin{array}{c}-0.170^{* * *} \\
(0.058)\end{array}$ & & \\
\hline Crisis dummy & & & $\begin{array}{c}-6.476^{* * *} \\
(1.285)\end{array}$ & \\
\hline BGR x Crisis dummy & & & $\begin{array}{c}2.256^{* * *} \\
(0.692)\end{array}$ & \\
\hline Herfindahl & & & & $\begin{array}{c}-0.162^{* *} \\
(0.079)\end{array}$ \\
\hline BGR x Herfindahl & & & & $\begin{array}{c}0.068^{* *} \\
(0.030)\end{array}$ \\
\hline MSA fixed effects & yes & yes & yes & yes \\
\hline Year fixed effects & yes & yes & yes & yes \\
\hline Observations & 6,407 & 4,925 & 6,407 & 6,407 \\
\hline R-squared & 0.591 & 0.590 & 0.595 & 0.591 \\
\hline Number of MSAs & 345 & 252 & 345 & 345 \\
\hline
\end{tabular}

Notes: This table reports fixed effects regressions of the log change in house price index on the Banking Granular Residual (BGR). Column (1) is the baseline scenario with the following explanatory variables: the current and lagged log change in MSAs income per capita, population and employment. Column (2) interacts the BGR with the housing supply elasticity by Saiz (2010). Column (3) introduces a crisis dummy that equals one for the period 2007-2009 and zero otherwise, plus an interaction with the BGR. Column (4) contains a MSA-level Herfindahl-Hirschman Index based on the volume of newly issued mortgage loans, both as single regressor and as an interaction term with the $B G R$. The sample of column (1) to (4) includes all U.S. metropolitan statistical areas for which mortgage and house price data is available for the period 1990-2014. All regressions include MSA and year fixed effects. Standard errors are robust to heteroskedasticity and are clustered at the MSA-level, ${ }^{* * *} p<0.01,{ }^{* *} p<0.05,{ }^{*} p<0.1$. 


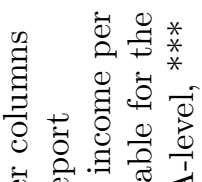

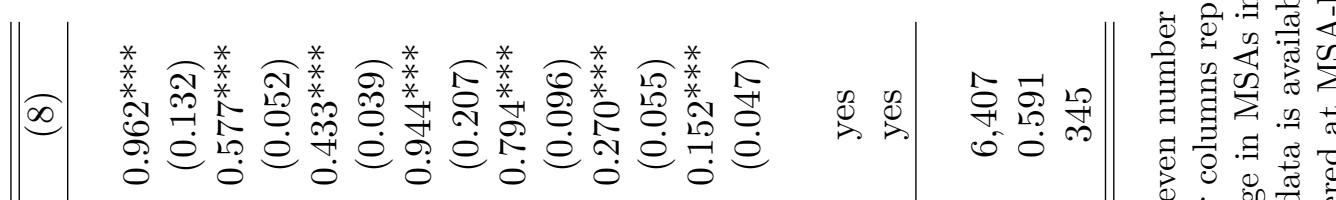

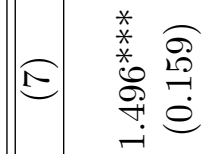

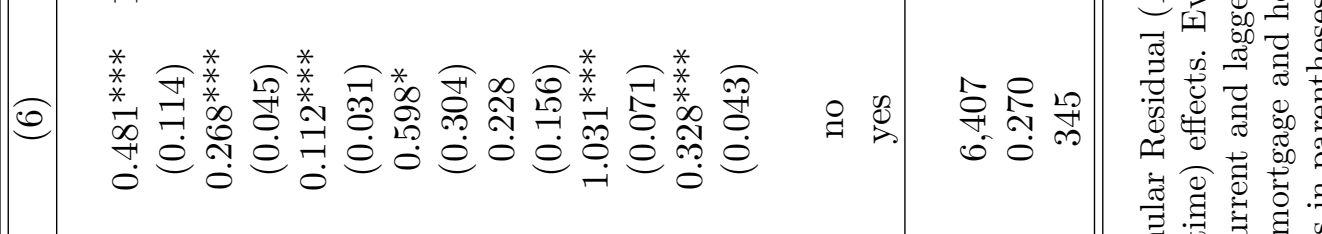

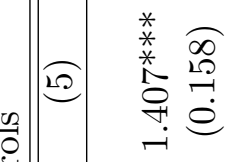

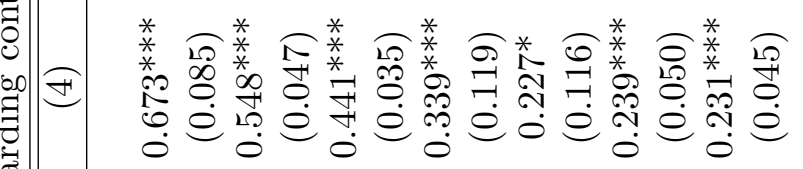

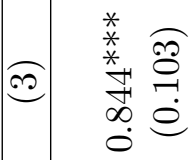

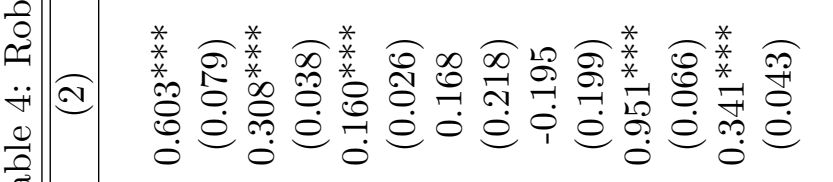

$$
\begin{aligned}
& \text { लำ }
\end{aligned}
$$

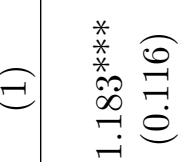

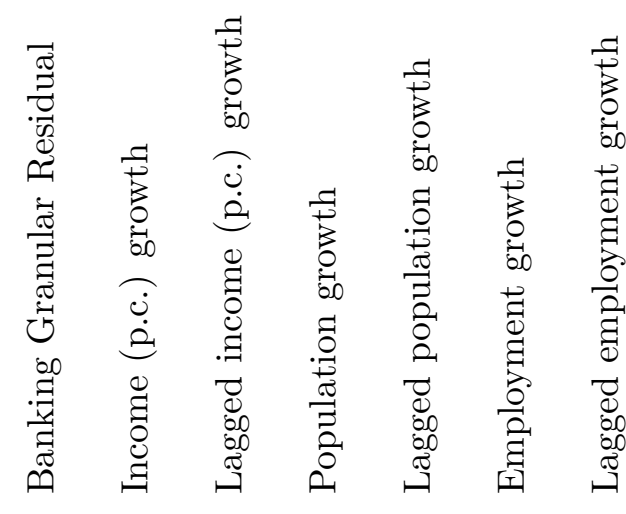

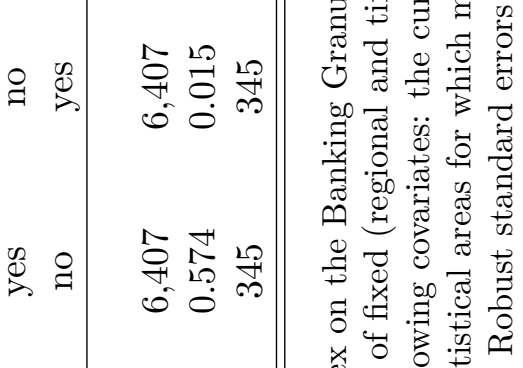

$$
\begin{aligned}
& \text { Ð } \\
& \text { \& } \\
& \text { 虽 } \\
& \text { 乎 } \\
& \text { g }
\end{aligned}
$$

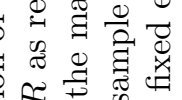

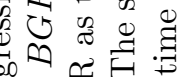

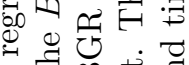

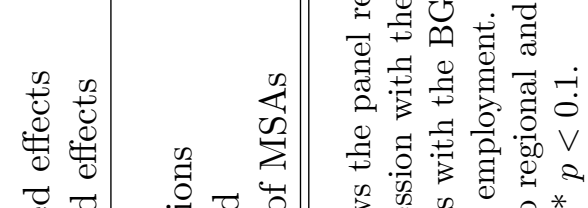

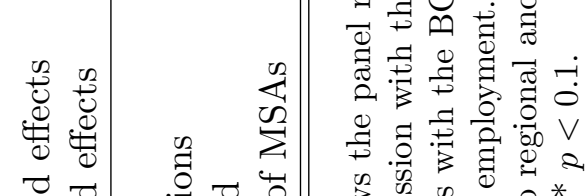

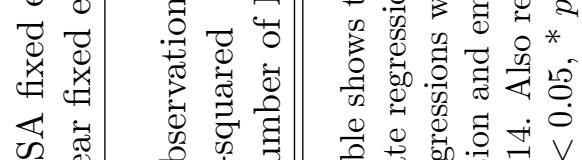

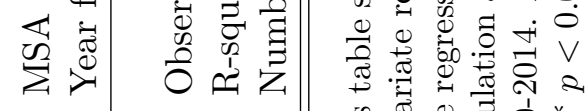

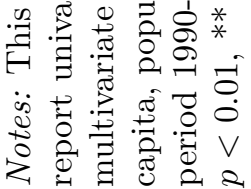


Table 5: Robustness regarding different mortgage shock specifications

\begin{tabular}{|c|c|c|c|c|}
\hline & $(1)$ & $(2)$ & $(3)$ & $(4)$ \\
\hline Banking Granular Residual 1 & $\begin{array}{c}0.962^{* * *} \\
(0.132)\end{array}$ & & & \\
\hline Banking Granular Residual 2 & & $\begin{array}{c}0.345^{* * *} \\
(0.119)\end{array}$ & & \\
\hline Banking Granular Residual 3 & & & $\begin{array}{c}1.544^{* * *} \\
(0.154)\end{array}$ & \\
\hline Banking Granular Residual 4 & & & & $\begin{array}{l}-0.083 \\
(0.143)\end{array}$ \\
\hline Income (p.c.) growth & $\begin{array}{c}0.577^{* * *} \\
(0.052)\end{array}$ & $\begin{array}{c}0.581^{* * *} \\
(0.052)\end{array}$ & $\begin{array}{c}0.581^{* * *} * \\
(0.051)\end{array}$ & $\begin{array}{c}0.584^{* * *} * \\
(0.052)\end{array}$ \\
\hline Lagged income (p.c.) growth & $\begin{array}{c}0.433^{* * *} \\
(0.039)\end{array}$ & $\begin{array}{c}0.434^{* * *} * \\
(0.039)\end{array}$ & $\begin{array}{c}0.437^{* * * *} \\
(0.039)\end{array}$ & $\begin{array}{c}0.440^{* * *} \\
(0.040)\end{array}$ \\
\hline Population growth & $\begin{array}{c}0.944^{* * *} \\
(0.207)\end{array}$ & $\begin{array}{c}0.938^{* * * *} \\
(0.207)\end{array}$ & $\begin{array}{c}0.940^{* * * *} \\
(0.205)\end{array}$ & $\begin{array}{c}0.956^{* * *} \\
(0.208)\end{array}$ \\
\hline Lagged population growth & $\begin{array}{c}0.794^{* * * *} \\
(0.096)\end{array}$ & $\begin{array}{c}0.787^{* * * *} \\
(0.097)\end{array}$ & $\begin{array}{c}0.789^{* * *} \\
(0.097)\end{array}$ & $\begin{array}{c}0.811^{* * *} \\
(0.096)\end{array}$ \\
\hline Employment growth & $\begin{array}{c}0.270^{* * *} \\
(0.055)\end{array}$ & $\begin{array}{c}0.276^{* * *} \\
(0.055)\end{array}$ & $\begin{array}{c}0.269^{* * *} \\
(0.055)\end{array}$ & $\begin{array}{c}0.275^{* * *} \\
(0.055)\end{array}$ \\
\hline Lagged employment growth & $\begin{array}{c}0.152^{* * *} \\
(0.047)\end{array}$ & $\begin{array}{c}0.160^{* * * *} \\
(0.047)\end{array}$ & $\begin{array}{c}0.139^{* * *} \\
(0.047)\end{array}$ & $\begin{array}{c}0.159^{* * *} \\
(0.047)\end{array}$ \\
\hline MSA $\mathrm{f}$ & yes & yes & yes & yes \\
\hline Year fixed effects & yes & yes & yes & yes \\
\hline Observations & 6,407 & 6,407 & 6,407 & 6,407 \\
\hline R-squared & 0.591 & 0.588 & 0.595 & 0.587 \\
\hline Number of MSAs & 345 & 345 & 345 & 345 \\
\hline
\end{tabular}

Notes: This table presents fixed effects regressions of the log change in house price index on different specifications of the Banking Granular Residual (BGR). Regressors are the current and lagged log change in MSAs income per capita, population and employment. Column (1) repeats our baseline regression based on Equation 2. Banking Granular Residual 2 refers to a measure of the idiosyncratic shock which is computed with bank, bank-time, year, and MSA fixed effects. The $B G R 3$ is based on shocks including only year, MSA and year-MSA fixed effects. For computing $B G R 4$, idiosyncratic shocks are measured with bank, MSA, time, bank-time and MSA-time fixed effects. The sample includes all U.S. MSAs for which mortgage and house price data are available for the period 1990-2014. Also, regional and time fixed effects are incrementally included. Robust standard errors are given in parentheses and clustered at the MSA-level, ${ }^{* * *} p<0.01,{ }^{* *} p<0.05$, ${ }^{*} p<0.1$. 
Table 6: IV regression

\begin{tabular}{|c|c|c|c|c|c|}
\hline & \multicolumn{3}{|c|}{ "Dependent variables } & \multirow[b]{2}{*}{$\begin{array}{l}\text { BGR } \\
(4)\end{array}$} & \multirow[b]{2}{*}{$\begin{array}{c}\text { House prices } \\
(5)\end{array}$} \\
\hline & $\begin{array}{c}\text { House prices } \\
(1)\end{array}$ & $\begin{array}{c}\mathrm{BGR} \\
(2)\end{array}$ & $\begin{array}{c}\text { House prices } \\
(3)\end{array}$ & & \\
\hline Banking Granular Residual & $\begin{array}{c}8.945^{* * *} \\
(2.515)\end{array}$ & & $\begin{array}{c}8.205 \\
(13.789)\end{array}$ & & \\
\hline Income (p.c.) growth & $\begin{array}{c}0.322^{* * *} \\
(0.060)\end{array}$ & $\begin{array}{c}0.006 \\
(0.005)\end{array}$ & $\begin{array}{c}0.371^{* * *} \\
(0.080)\end{array}$ & $\begin{array}{c}0.003 \\
(0.005)\end{array}$ & $\begin{array}{c}0.399 * * * \\
(0.066)\end{array}$ \\
\hline Lagged income (p.c.) growth & $\begin{array}{c}0.444^{* * *} \\
(0.065)\end{array}$ & $\begin{array}{c}0.001 \\
(0.005)\end{array}$ & $\begin{array}{c}0.493^{* * *} \\
(0.081)\end{array}$ & $\begin{array}{c}0.002 \\
(0.006)\end{array}$ & $\begin{array}{c}0.512^{* * *} \\
(0.076)\end{array}$ \\
\hline Population growth & $\begin{array}{c}0.873^{* * *} \\
(0.233)\end{array}$ & $\begin{array}{c}0.001 \\
(0.016)\end{array}$ & $\begin{array}{c}0.858^{* * *} \\
(0.308)\end{array}$ & $\begin{array}{l}-0.007 \\
(0.018)\end{array}$ & $\begin{array}{c}0.801^{* *} \\
(0.339)\end{array}$ \\
\hline Lagged population growth & $\begin{array}{c}1.124^{* * *} \\
(0.164)\end{array}$ & $\begin{array}{c}0.002 \\
(0.015)\end{array}$ & $\begin{array}{c}1.122^{* * *} \\
(0.203)\end{array}$ & $\begin{array}{l}-0.001 \\
(0.018)\end{array}$ & $\begin{array}{l}1.11^{* * *} \\
(0.268)\end{array}$ \\
\hline Employment growth & $\begin{array}{l}0.139 * \\
(0.078)\end{array}$ & $\begin{array}{c}0.002 \\
(0.006)\end{array}$ & $\begin{array}{c}0.073 \\
(0.090)\end{array}$ & $\begin{array}{c}0.001 \\
(0.007)\end{array}$ & $\begin{array}{c}0.084 \\
(0.095)\end{array}$ \\
\hline Lagged employment growth & $\begin{array}{c}0.218^{* * *} \\
(0.083)\end{array}$ & $\begin{array}{l}-0.001 \\
(0.007)\end{array}$ & $\begin{array}{c}0.199 \\
(0.127)\end{array}$ & $\begin{array}{l}-0.005 \\
(0.008)\end{array}$ & $\begin{array}{c}0.158 \\
(0.113)\end{array}$ \\
\hline Lagged deregulation & & $\begin{array}{c}-0.055^{* * *} \\
(0.015)\end{array}$ & & $\begin{array}{c}-0.023 \\
(0.03)\end{array}$ & $\begin{array}{l}-0.192 \\
(0.288)\end{array}$ \\
\hline $\begin{array}{l}\text { First stage F-test } \\
\text { P-value }\end{array}$ & & $\begin{array}{l}13.80 \\
0.000\end{array}$ & & $\begin{array}{c}0.51 \\
0.4776\end{array}$ & \\
\hline $\begin{array}{l}\text { MSA fixed effects } \\
\text { Year fixed effects }\end{array}$ & $\begin{array}{l}\text { yes } \\
\text { yes }\end{array}$ & $\begin{array}{l}\text { yes } \\
\text { yes }\end{array}$ & $\begin{array}{l}\text { yes } \\
\text { yes }\end{array}$ & $\begin{array}{l}\text { yes } \\
\text { yes }\end{array}$ & $\begin{array}{l}\text { yes } \\
\text { yes }\end{array}$ \\
\hline $\begin{array}{l}\text { Observations } \\
\text { R-squared (centered) } \\
\text { Number of MSAs }\end{array}$ & $\begin{array}{c}2,159 \\
0.303 \\
243\end{array}$ & 2,159 & $\begin{array}{c}1,466 \\
0.432 \\
166\end{array}$ & 1,466 & $\begin{array}{c}1,508 \\
0.497 \\
208\end{array}$ \\
\hline
\end{tabular}

Notes: This table presents the instrumental variable (IV) estimation strategy. The main variable of interest, the $B G R$, is instrumented with the lagged Index of Branching Deregulation from Rice and Strahan (2010). The index ranges between zero and four whereas we reverse the index so that most restricted states get a zero and the least restrictive states a four. Column (1) and (2) display the second stage and first stage, respectively, of the 2SLS estimation based on the whole sample where the deregulation index is available. Column (3) and (4) represents the second and first stage, respectively, of the 2SLS regression based on a sample restricted to deregulation values ranging between zero and two. Column (5) demonstrates the reduced form of the regression of house price growth on the instrument. The sample of Columns (1) and (2) is restricted to 243 MSAs for the period 1994-2005 due to the availability of the deregulation index. 